\title{
Ileal digestibility and endogenous protein losses of milk replacers based on whey proteins alone or with an enzyme-treated soybean meal in young dairy calves
}

\author{
I. Ansia, ${ }^{1} \oplus$ H. H. Stein, ${ }^{1}$ D. A. Vermeire, ${ }^{2}$ C. Brøkner, ${ }^{3}$ and J. K. Drackley ${ }^{1 *}$ () \\ ${ }^{1}$ Department of Animal Sciences, University of Illinois, Urbana 61801 \\ ${ }^{2}$ Nouriche Nutrition, Lake St. Louis, MO 63367 \\ ${ }^{3}$ Hamlet Protein A/S, 8700 Horsens, Denmark
}

\begin{abstract}
Our objective was to measure and compare apparent ileal digestibility, standard ileal digestibility, and true ileal digestibility of crude protein $(\mathrm{CP})$ and amino acids (AA) in milk replacers (MR) containing all milk proteins (WPC) or with $50 \%$ of the $\mathrm{CP}$ provided by an enzyme-treated soybean meal (ESBM). A T-cannula was placed in the ileum of 9 Holstein calves ( 8 males and 1 freemartin female) at approximately $15 \mathrm{~d}$ of age. After 2 wk postsurgery, calves were randomly assigned to a $3 \times 3$ replicated Latin square with 5 -d periods. Calves were fed twice daily at a rate of $2 \%$ (dry matter) of body weight $(1.25 \mathrm{~kg} / \mathrm{d}$ on average), reconstituted to $15 \%$ solids, and adjusted weekly. No starter was offered to minimize rumen development. Digesta samples were collected continuously during $12 \mathrm{~h}$ on $\mathrm{d} 4$ and 5 of each period. Basal endogenous losses of AA and $\mathrm{CP}$ were estimated by feeding an $\mathrm{N}$-free $\mathrm{MR}$ to each calf during 1 period. Total endogenous losses (basal + specific; $\left.\mathrm{END}_{\text {total }}\right)$ were estimated by multivariate regression of the chi-squared distances between digesta and reference protein AA profiles. Ileal digesta $\mathrm{pH}$ with the ESBM diet was lower than that with the WPC diet. According to the piecewise nonlinear model of $\mathrm{pH}$ fluctuation, digesta $\mathrm{pH}$ during ESBM decreased more slowly after feeding and reached its nadir later than with the WPC diet. Diet did not affect average daily gain, but calves on the ESBM diet showed a bigger increment of withers height and lower mean fecal scores. The basal endogenous losses of AA and CP were $13.9 \pm 1.1$ and $22.4 \pm 1.1 \mathrm{~g} / \mathrm{kg}$ of dry matter intake, respectively. The estimated $\mathrm{END}_{\text {total }}$ of $\mathrm{AA}$ and $\mathrm{CP}$ was higher with ESBM than with WPC. Accordingly, apparent ileal digestibility and standard ileal digest-
\end{abstract}

Received October 3, 2019.

Accepted January 7, 2020.

*Corresponding author: drackley@illinois.edu ibility of most AA, CP, and total AA were lower or tended to be lower with ESBM. However, true ileal digestibility did not differ between diets for $\mathrm{CP}$ and all AA except Ala and Ile, which were greater with WPC, and Arg, which tended to be greater with ESBM. In agreement with the estimated differences in $\mathrm{END}_{\text {total }}$, we found that flows of digesta DNA and crude mucin were greater with ESBM. Substitution of $50 \%$ of the protein from whey with enzymatically treated soybean meal did not affect major nutrient digestibility or calf growth and even improved fecal consistency. Adjusting digestibilities of $\mathrm{CP}$ and $\mathrm{AA}$ in MR by endogenous protein losses is crucial when comparing bioavailability of alternative proteins and milk proteins.

Key words: whey, enzyme-treated soy, ileal digestibility, endogenous protein, calf

\section{INTRODUCTION}

Milk components are the most expensive ingredients in calf milk replacers (MR; Drackley, 2008). Whey proteins and dried skim milk are among the most common milk-derived ingredients used for calf MR, and therefore total or partial substitution of milk proteins by alternative protein sources can be economically beneficial (Raeth et al., 2016). In the actual economic situation, the price of soy protein remains less than whey protein (Gro Intelligence, 2017), and therefore it is still one of the most studied alternatives. However, soybean protein as a milk protein substitute in calf MR has not been completely satisfactory because of the presence of antinutritional factors (ANF; Lallès, 1993). Protease inhibitors, lectins, antigenic proteins, polyphenols, oligosaccharides, goitrogens, phytates, and saponins are among the ANF with a significant negative effect on calf performance (Huisman and Jansman, 1991).

Microbial-treated soy protein has become a feed ingredient of interest for dairy calves due to its lower concentration of ANF (Chompreeda and Fields, 1984; Feng et al., 2007), the higher proportion of AA and small 
peptides (Kim et al., 2010), and the presence of other beneficial bioactive compounds and peptides (Sun et al., 2010; Chatterjee et al., 2018). Microbial-treated soy protein seems to enhance the immune system in preand postweaning calves (Kim et al., 2010, 2012; Kwon et al., 2011) and improve weight gain through better digestive enzyme activity and intestinal morphology (Kiers et al., 2003; Feng et al., 2007). Microbial-treated soy protein has been proven to constitute a satisfactory substitute for milk proteins in MR for young dairy calves (Mir et al., 1991) and even showed an elevated enzymatic digestibility in vitro (Kiers et al., 2000). This processing method can be achieved through the inoculation of different types of microorganisms, which will affect the characteristics of the final product differently (Chompreeda and Fields, 1984). Enzymatic treatment of soybean meal provides all of the aforementioned advantages in terms of ANF reduction and improved digestibility (Cervantes-Pahm and Stein, 2010) while ensuring a more homogeneous final product due to the lack of lactic acid production during bacterial fermentation (Kay, 1926; Pederson and Albury, 1955). To our knowledge, no attempt has been made to evaluate the ileal digestibility of an enzyme-treated soy protein in young preweaning calves.

A meticulous evaluation of the bioavailability of dietary AA is critical to determine the protein quality and nutritional value of different protein sources. Comparisons of apparent ileal digestibility (AID) of $\mathrm{CP}$ or AA from different feed sources can lead to misleading conclusions because an important percentage of the digesta AA that have not been reabsorbed at the ileum is synthesized endogenously (Nyachoti et al., 2010). Endogenous protein secretions comprise mucus, sloughed cells, serum albumin, digestive enzymes, amides, ingested hair, and bacteria, among other compounds. Endogenous protein losses can be classified as either basal or specific (Stein et al., 2007). Basal losses are considered fairly constant, whereas specific losses depend on the composition of the diet and increase when fiber and ANF increase in the diet (Montagne et al., 2001). Feeding an N-free diet allows determination of basal endogenous losses to calculate standard ileal digestibility (SID; Montagne et al., 2003). The digesta at the ileum is a mixture of proteins with different origins (dietary, the animal itself or "host," and microbial) and therefore different AA profiles (Guilloteau et al., 1983). The proportions of each protein in digesta can be estimated to calculate total endogenous protein losses $\left(\mathbf{E N D}_{\text {total }}\right)$ to obtain the true ileal digestibility (TID; Duvaux et al., 1990) of the dietary proteins. Our objective was to measure and compare AID, SID, and TID of MR based either entirely on milk (whey) proteins or on whey plus an enzymatically treated soybean meal replacing $50 \%$ of the total protein. Our hypothesis was that the inclusion of an enzyme-treated soybean meal in the MR would not affect the TID of dietary proteins once ileal flows were corrected by the endogenous protein losses.

\section{MATERIALS AND METHODS}

\section{Animals and Treatments}

The Institutional Animal Care and Use Committee of the University of Illinois at Urbana-Champaign approved all procedures (protocol no. 18053). Nine Holstein calves ( 8 males and 1 freemartin female) were transported at approximately $2 \mathrm{~d}$ of age from a commercial dairy farm to the Nutrition Field Laboratory at the University of Illinois. Calves were housed individually in outdoor polyvinyl chloride hutches placed on crushed limestone and bedded with sand. Calves were fed a commercial MR (28.5\% CP, 15\% fat; Excelerate, Milk Specialties Global Animal Nutrition, Eden Prairie, MN) twice daily (0700 and $1900 \mathrm{~h}$ ). Milk replacer was reconstituted to $15 \%$ solids and fed at a rate of $1.5 \%$ (DM) of BW during wk 1 and $2 \%$ of BW thereafter, adjusted weekly or every $5 \mathrm{~d}$ once the experimental period began $(1.25 \mathrm{~kg}$ of $\mathrm{MR} \mathrm{DM} / \mathrm{d}$ on average during the experimental period). Calves had ad libitum access to water, but no solid feed was offered during the trial to minimize rumen development.

At 15 d after arrival, calves were fitted surgically with a T-cannula at the terminal ileum. A more detailed description of the surgery and postsurgical care can be found elsewhere (Ansia et al., 2019). After $1 \mathrm{wk}$ of recovery, all calves were switched to the all-whey experimental MR to accustom calves to the new formulation and to avoid refusals at the beginning of the experimental period. After 2 wk postsurgery, calves were blocked by BW and randomly assigned to a replicated $3 \times 3$ Latin square design with 5 -d periods where the first $3 \mathrm{~d}$ were used for diet adaptation and the last 2 $\mathrm{d}$ were used for sampling. The 3 experimental diets were a control MR with whey protein concentrate as the only source of protein (WPC), an isonitrogenous $\mathrm{MR}$ in which $50 \%$ of the protein was provided from an enzyme-treated soybean meal (ESBM; HP-100, Hamlet Protein A/S, Horsens, Denmark), and an N-free MR (NFree). Chromic oxide (0.2\%, DM basis) was fed with the MR as an indigestible marker for the solid phase of the digesta, whereas the complex Co-Na-EDTA $(0.85 \%$, DM basis) was used as a marker for the liquid phase (Udén et al., 1980). Diet and chemical composition of each MR are summarized in Tables 1 and 2. 
Table 1. Diet and chemical composition of milk replacers

\begin{tabular}{|c|c|c|c|c|}
\hline \multirow[b]{2}{*}{ Item } & \multicolumn{3}{|c|}{ Diet $^{1}$} & \multirow[b]{2}{*}{$\mathrm{SD}$} \\
\hline & WPC & ESBM & NFree & \\
\hline \multicolumn{5}{|l|}{ Diet ingredient, \% } \\
\hline Whey protein concentrate & 36.5 & 18.3 & & \\
\hline $\mathrm{HP}-100^{2}$ & & 24.1 & & \\
\hline Lactose & 48.9 & 42.1 & 82.6 & \\
\hline Crystallized fat & 11.0 & 12.0 & 13.9 & \\
\hline Vitamin-mineral mix & 2.5 & 2.5 & 2.5 & \\
\hline Co-EDTA & 0.8 & 0.8 & 0.8 & \\
\hline $\mathrm{CrO}_{2}$ & 0.2 & 0.2 & 0.2 & \\
\hline \multicolumn{5}{|c|}{ Chemical composition, $\mathrm{g} / \mathrm{kg}$ unless noted } \\
\hline $\mathrm{CP}$ & 275.04 & 280.64 & 2.61 & 2.98 \\
\hline Fatty acids & 97.8 & 98.2 & 86.6 & 12.9 \\
\hline Sugars $^{3}$ & 441 & 414 & 716 & 16 \\
\hline Lactose & 430 & 404 & 706 & 15 \\
\hline Ash & 65.1 & 71.1 & 66.3 & 3.4 \\
\hline $\mathrm{Ca}$ & 12.4 & 13.4 & 12.7 & 0.65 \\
\hline $\mathrm{P}$ & 6.60 & 7.14 & 6.59 & 0.35 \\
\hline $\mathrm{Na}$ & 0.31 & 0.23 & 0.71 & 0.12 \\
\hline $\mathrm{K}$ & 8.35 & 8.60 & 7.50 & 0.15 \\
\hline $\mathrm{Cl}$ & 3.15 & 1.15 & 6.75 & 0.15 \\
\hline $\mathrm{Mg}$ & 0.75 & 1.60 & 1.00 & 0.1 \\
\hline $\mathrm{Cu}, \mathrm{mg} / \mathrm{kg}$ & 9.4 & 11.9 & 17.4 & 5.4 \\
\hline $\mathrm{Fe}, \mathrm{mg} / \mathrm{kg}$ & 143 & 138 & 277 & 88 \\
\hline $\mathrm{Zn}, \mathrm{mg} / \mathrm{kg}$ & 74.3 & 85.3 & 123 & 28 \\
\hline $\mathrm{Mn}, \mathrm{mg} / \mathrm{kg}$ & 47.2 & 57.1 & 96.7 & 11 \\
\hline NDF & - & 22.5 & - & 4 \\
\hline Osmolality, ${ }^{4} \mathrm{mOsm} / \mathrm{kg}$ & 329 & 311 & 476 & 5 \\
\hline
\end{tabular}

${ }^{1}$ Calves were fed a whey-based (WPC), enzyme-treated soy-based (ESBM), or N-free (NFree) milk replacer $2 \times$ daily for $5 \mathrm{~d}$ at a rate of $2 \%$ of BW (DM basis).

${ }^{2}$ HP-100 = enzyme-treated soybean meal (Hamlet Protein A/S, Horsens, Denmark).

${ }^{3}$ Sum of the assayed sugars (fructose, glucose, sucrose, maltose, and lactose).

${ }^{4}$ Osmolality estimated by adding the moles of all assayed sugars and minerals provided per kilogram of the milk replacer solution.

Table 2. Amino acid profile $(\mathrm{g} / 100 \mathrm{~g}$ of $\mathrm{CP})$ of milk replacers

\begin{tabular}{lrrr}
\hline & \multicolumn{3}{c}{ Diet $^{2}$} \\
Item & \\
\cline { 2 - 3 } & WPC & ESBM & SD \\
\hline Ala & 5.41 & 4.84 & 0.21 \\
Arg & 3.07 & 4.92 & 0.21 \\
Asx & 12.25 & 11.85 & 0.47 \\
Cys & 3.22 & 2.40 & 0.23 \\
Glx & 17.58 & 17.44 & 0.65 \\
Gly & 2.13 & 3.06 & 0.13 \\
His & 2.26 & 2.36 & 0.13 \\
Ile & 6.48 & 5.68 & 0.21 \\
Leu & 13.34 & 10.64 & 0.38 \\
Lys & 10.88 & 8.52 & 0.17 \\
Met & 3.09 & 3.25 & 1.34 \\
Phe & 4.21 & 4.70 & 0.18 \\
Pro & 5.26 & 4.95 & 0.46 \\
Ser & 3.98 & 4.15 & 0.19 \\
Thr & 5.36 & 4.62 & 0.18 \\
Trp & 2.67 & 1.96 & 0.43 \\
Tyr & 3.56 & 3.49 & 0.33 \\
Val & 5.93 & 5.44 & 0.36 \\
\hline
\end{tabular}

${ }^{1}$ Asx $=$ asparagine plus aspartate; Glx = glutamine plus glutamate.

${ }^{2}$ Calves were fed an either whey-based (WPC) or enzyme-treated soybased (ESBM) milk replacer $2 \times$ daily for $5 \mathrm{~d}$ at a rate of $2 \%$ of BW (DM basis).

\section{Measurements and Chemical Analysis}

On d 4 and 5 of each period, a 250-mL plastic bag (Nurser standard liners, Playtex, North Bergen, NJ) was attached to the cannula with an auto-locking cable tie after removing the cannula cap. Bags were removed when full or approximately every $30 \mathrm{~min}$ continuously for $12 \mathrm{~h}$ (between the a.m. and p.m. meals). The content of each bag was weighed, digesta $\mathrm{pH}$ was measured immediately with a portable $\mathrm{pH}$ meter (Accumet AP110, Fisher Scientific, Atlanta, GA), and digesta was frozen thereafter. Samples were pooled by calf and period. Milk replacer samples were collected on d 4 and 5 of each period and composited by period before analysis. Dry matter and ash were determined on all MR and freeze-dried digesta by drying in an oven at $65^{\circ} \mathrm{C}$ for $24 \mathrm{~h}$ and $600^{\circ} \mathrm{C}$ for $3 \mathrm{~h}$, respectively. Crude protein was determined with the combustion method (AOAC International, 2006; method 990.03). The following AOAC International (2006) methods for the complete AA profile (982.30), fatty acids (996.06), minerals (Ca, $\mathrm{P}, \mathrm{Na}, \mathrm{K}, \mathrm{Cl}, \mathrm{Mg}, \mathrm{Cu}, \mathrm{Fe}, \mathrm{Zn}, \mathrm{Mn}$; 985.01), chromium (998.08), cobalt (990.08), sugars (Mason and Slover, 
1971), and NDF (Robertson and Van Soest, 1981) on feed and digesta were performed at the Agricultural Experimental Station Laboratory of the University of Missouri-Columbia.

Total DNA was extracted from freeze-dried digesta using a QIAamp PowerFecal DNA kit (catalog no. 12830-50; Qiagen, Hilden, Germany). Sample DNA concentration was quantified using a Nanodrop spectrophotometer (Nyxor Biotech, Paris, France). Total crude mucin content was measured after fractionation of ileal digesta according to Montoya et al. (2015). Individual freeze-dried digesta samples were reconstituted (1:20, $\mathrm{wt} / \mathrm{vol})$ in saline solution $(0.15 \mathrm{~mol} / \mathrm{L})$ and centrifuged $\left(14,500 \times g\right.$ for $30 \mathrm{~min}$ at $\left.4^{\circ} \mathrm{C}\right)$. The supernatant was mixed $(1: 1.5, \mathrm{vol} / \mathrm{vol})$ with ethanol at $0^{\circ} \mathrm{C}$, kept overnight at $-20^{\circ} \mathrm{C}$, and centrifuged at $1,400 \times g$ for 10 min at $4^{\circ} \mathrm{C}$. The crude mucin precipitate was recovered in $15 \mathrm{~mL}$ of saline solution and precipitated again with ethanol in the same conditions. The final crude mucin precipitate was recovered in $10 \mathrm{~mL}$ of saline solution, freeze-dried, and weighed (Piel et al., 2004).

Body weight was recorded at the beginning and end of each 5-d period, whereas water and milk intakes were measured daily. Respiratory health (eye, nasal, and breathing scores) and fecal consistency were scored twice daily by the same person throughout the entire experiment.

\section{Flows of Nutrients, AID, and SID}

The flow of any nutrient expressed in grams per kilogram of DMI was calculated by multiplying its concentration (DM basis) in digesta by the flow of DM, calculated using the following equation:

$$
\mathrm{DM} \text { flow }=\text { Marker }_{\text {diet }} / \text { Marker }_{\text {digesta }},
$$

where Marker $_{\text {diet }}$ and Marker digesta $_{\text {are the average of }}$ $\mathrm{Co}$ and $\mathrm{Cr}$ concentration $(\mathrm{g} / \mathrm{kg}$ of $\mathrm{DMI})$ in diet and digesta, respectively (Van Bruchem et al., 1997).

The AID of any nutrient was calculated using the following equation:

$$
\begin{gathered}
\text { AID, } \%=\left[1-\left(\text { Nutrient }_{\text {digesta }} / \text { Nutrient }_{\text {diet }}\right)\right. \\
\left.\times\left(\text { Marker }_{\text {diet }} / \text { Marker }_{\text {digesta }}\right)\right] \times 100,
\end{gathered}
$$

where Nutrient $_{\text {digesta }}$ and Nutrient diet $_{\text {are the concentra- }}$ tions $(\mathrm{g} / \mathrm{kg})$ in digesta and diet (DM basis), respectively. Basal ileal endogenous losses (END $_{\text {basal }}$; expressed as $\mathrm{g} / \mathrm{kg}$ of DMI) of $\mathrm{CP}$ or AA were calculated using the AA concentrations found in digesta during the NFree treatment in the following equation:

$$
\mathrm{END}_{\text {basal }}=\mathrm{AA}_{\text {digesta }} \times\left(\text { Marker }_{\text {diet }} / \text { Marker }_{\text {digesta }}\right),[3]
$$

where $\mathrm{AA}_{\text {digesta }}$ is the concentration of each $\mathrm{AA}$ or $\mathrm{CP}$ in ileal digesta (DM basis). Therefore, with the values previously calculated (Equations 2 and 3), the SID was calculated according to Equation 4:

$$
\mathrm{SID}, \%=\mathrm{AID}+\left[\left(\mathrm{END}_{\text {basal }} / \mathrm{AA}_{\text {diet }}\right) \times 100\right],
$$

where $\mathrm{AA}_{\text {diet }}$ is the concentration of each $\mathrm{AA}$ or $\mathrm{CP}$ in the diet (DM basis).

\section{Estimation of Total Ileal Endogenous Losses of AA and TID}

Total (basal + specific) endogenous losses of AA or $\mathrm{CP}$ and the proportions of the different endogenous and dietary proteins in the digesta were estimated using the method proposed by Duvaux et al. (1990). This method uses multiple regression analysis to estimate the theoretical proportions of each protein that minimizes the chi-squared distance with respect to the composition of AA of the digesta. The chi-squared distance between 2 proteins $(i$ and $j$ ) is calculated according to the following equation:

$$
\chi^{2}=\left(\frac{\mathrm{AA}_{i j}}{\sqrt{\mathrm{AA}_{i j}}}-\frac{\mathrm{AA}_{i k}}{\sqrt{\mathrm{AA}_{i j}}}\right)^{2},
$$

where $\mathrm{AA}_{i j}$ and $\mathrm{AA}_{i k}$ are the percentages of $\mathrm{AA}_{k}$ in the sum of all the analyzed AA $(k=17)$ in proteins $i$ and $j$, respectively. The lower the chi-squared distance, the higher the similarity between the proteins involved in each comparison.

Reference AA profiles for estimation of the origin of the different endogenous proteins were selected according to Montagne et al. (2000b). The mean AA profile of axenic lamb feces (Combe, 1976) and calf meconium (Grongnet et al., 1981) was used as a reference for the endogenous protein from the calf (host), whereas the mean AA composition of fecal bacteria from pig (Mason et al., 1976) and sheep (Mason, 1979) was used as a reference for endogenous bacterial protein.

Flows of $\mathrm{END}_{\text {total }}(\mathrm{g} / \mathrm{kg}$ of DMI) were calculated by applying the sum of estimated percentages of host and bacterial proteins to the total output of AA at the ileum. The TID was calculated according to the following equation:

$$
\mathrm{TID}, \%=\mathrm{AID}+\left[\left(\mathrm{END}_{\text {total }} / \mathrm{AA}_{\text {diet }}\right) \times 100\right] .
$$




\section{Statistical Analysis}

Data for ileal $\mathrm{pH}$ were first averaged by hour, and comparisons of mean $\mathrm{pH}$ per diet were obtained using PROC MIXED in SAS version 9.4 (SAS Institute Inc., Cary, NC) with the REPEATED statement. The covariance structure that resulted in the smallest Bayesian and Akaike information criterion was chosen. Period, treatment, and postfeeding hour plus its interaction with treatment were included as fixed effects, and time nested within calf and day was included as a random effect. The SLICE statement was used to find differences in the interaction between treatments and time. Initial $\mathrm{pH}$ values and a set of variables representing the sequence of treatments, to account for the carry-over effect, were included as covariates. Digesta $\mathrm{pH}$ least squares means per hour obtained from this method were fitted into the best possible broken-line model (Ansia et al., 2019) according to the adjusted coefficient of determination value, significance of the model parameter estimates, and visual appraisal of the residuals using NLREG (version 6.5; Sherrod, 1991). Digesta $\mathrm{pH}$ fluctuation was fitted according to the equation

$$
\begin{aligned}
\mathrm{pH}=\left[\mathrm{b}_{1}\right. & \times \max (0, \text { time })]+\left[\mathrm{b}_{2} \times \max \left(0, \text { time }-\mathrm{x}_{1}\right)\right] \\
& +\left\{\mathrm{a}_{0}+\left[\mathrm{b}_{3} \times \max \left(0, \text { time }-\mathrm{x}_{2}\right)\right]\right\},
\end{aligned}
$$

where $a_{0}$ is the estimate of initial $\mathrm{pH}, \mathrm{b}_{1}$ and $\mathrm{b}_{3}$ are the 2 positive slopes and $b_{2}$ is the negative slope, $x_{1}$ and $\mathrm{x}_{2}$ are the estimates of the time points where a significant change in slope occurred (knots), and time is the hour after feeding the morning meal. Differences of model parameters between treatments were tested by performing a $t$-test to evaluate the significance of a "dummy variable" estimate that represented the difference between the estimates for that particular parameter on each model.

Digesta $\mathrm{pH}$ area above the curve was calculated with the trapezoid method using the first $\mathrm{pH}$ value on each collection day as a baseline $\mathrm{pH}$ to create the successive trapezoids. Comparisons between treatments for mean digesta $\mathrm{pH}$, area above the curve, $\mathrm{BW}$ difference and percentage change, milk and water intake, and fecal scores were analyzed as mixed-effect models with treatment, period, and day (only for intakes and fecal scores) as fixed effects, calf as random effect, and the carryover variables as covariates within PROC MIXED in SAS. Comparisons between diets for AID, SID, TID, and flow of nutrients were performed using PROC MIXED with diet and period as fixed factors and with calf and calf nested within period as random effects. When applicable, $P$-values for the comparisons among the 3 diets were adjusted using the Tukey-Kramer method. In ad- dition, the $P$-values for the contrast between the WPC and ESBM diets were obtained with the CONTRAST statement in PROC MIXED. Assumptions about the normality and homogeneity of residuals derived from all the ANOVA were checked using PROC UNIVARIATE and the INFLUENCE option within PROC MIXED in SAS.

\section{RESULTS}

\section{Body Growth, Intake, and Health Scores}

There were no differences in MR intake among diets, but water intake was higher when calves were fed the NFree diet than when fed the other 2 diets (Table 3 ). Fecal scores also were affected by diet $(P<0.01)$. The NFree diet induced high scores (i.e., very fluid feces), the ESBM diet resulted in the lowest scores, and the WPC diet induced intermediate values. We found no differences in BW gain or increment between the WPC and ESBM diets; however, when fed the NFree diet, calves lost $2.35 \mathrm{~kg}$ during the 5 -d periods. Diet affected all body frame dimensions except body length and hip height. Calves fed the ESBM diet showed greater $(P$ $=0.02$ ) change and increment in withers height than those fed the WPC diet. In addition, calves fed the ESBM diet had a greater increment and change in hip width compared with calves fed the NFree diet (Supplemental Table S1; https://doi.org/10.3168/jds.2019 -17699). Among all the signs of impaired respiratory health, diet affected only the probability of suffering nasal discharge $(P=0.04)$. Calves fed the ESBM diet had significant 0.23 -fold lower odds of showing any kind of nasal discharge, whereas calves fed the WPC diet showed only a tendency (Supplemental Table S2; https: //doi.org/10.3168/jds.2019-17699).

\section{Digesta Flow and Digesta $\mathrm{pH}$}

Flow of DM at the ileum was greatest when calves were fed the NFree diet and lowest when calves were fed the WPC diet, whereas ESBM was intermediate (Table 4). We observed no differences in the amount of digesta collected between the WPC and ESBM diets, but during the NFree treatment the amount of digesta was approximately 2.5-fold higher and had an approximately 2-fold lower DM content. Diet affected mean digesta $\mathrm{pH}$ and its fluctuation across time. The NFree treatment had the highest mean $\mathrm{pH}$ because, unlike the other treatments, digesta $\mathrm{pH}$ did not decrease after feeding (NFree $\times$ hour; $P=0.76$ ). Digesta $\mathrm{pH}$ was lowest when calves were fed the ESBM diet. According to the parametrization of the $\mathrm{pH}$ fluctuation data, digesta $\mathrm{pH}$ decreased slower after feeding and reached its nadir 
Table 3. Body weight change, intakes, and fecal score by diet

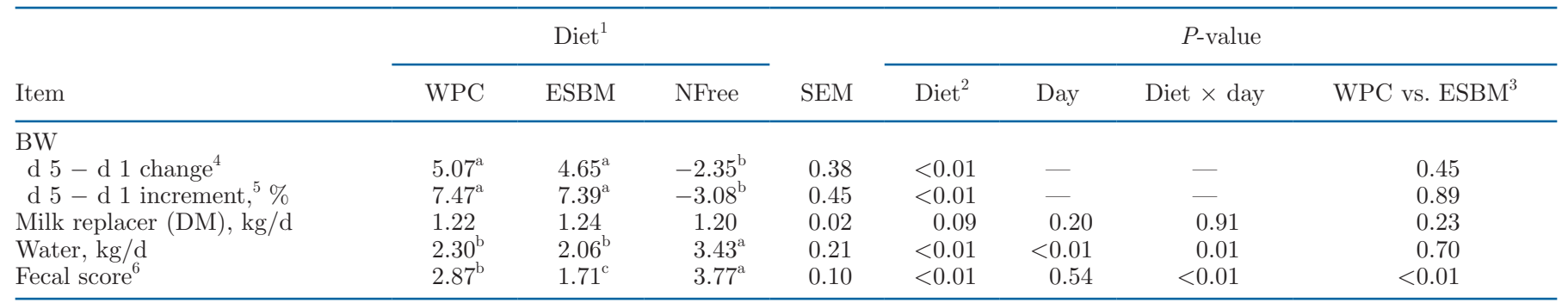

${ }^{\mathrm{a}-\mathrm{c}}$ Least squares means within a row with different superscripts are different $(P<0.05)$ with the Tukey-Kramer adjustment.

${ }^{1}$ Calves were fed a whey-based (WPC), enzyme-treated soy-based (ESBM), or N-free milk replacer $2 \times$ daily for $5 \mathrm{~d}$ at a rate of $2 \%$ of BW (DM basis).

${ }^{2} P$-value for the difference in apparent ileal digestibility between the WPC, ESBM, and NFree diets.

${ }^{3} P$-value for the contrast between the WPC and ESBM diets.

${ }^{4}$ Difference between the parameter value on the last day (d 5) and first day (d 1) on each diet.

${ }^{5}$ Difference between the parameter value on the last day (d 5) and first day (d 1) on each diet as a percentage of the initial value (d 1).

${ }^{6}$ Fecal scores were assigned twice per day (before each meal) based on the following values: 1 = normal, solid; $2=$ semi-formed, pasty; $3=$ loose, but stays on top of bedding; 4 = watery, sifts through bedding.

later with the ESBM diet than with the WPC diet (Figure 1). Consequently, ESBM also showed the biggest area above the curve.

\section{AID of OM and Non-N Milk Components}

The actual power of test for AID of DM with $\alpha=$ 0.05 and $\mathrm{n}=9$ was 0.77 . Apparent digestibilities of $\mathrm{OM}$, sucrose, $\mathrm{Zn}, \mathrm{Mn}$, and maltose were higher with the WPC diet than with the ESBM diet (Table 5). The
NFree diet resulted in the lowest AID of OM, fatty acids, fructose, glucose, lactose, ash, Ca, P, and Mg. Apparent digestibility of $\mathrm{Zn}$ was greater with the ESBM diet than with the WPC or NFree diets.

\section{Digestibilities of $A A$ and $C P$}

A tendency was detected for greater AID and SID for the sum of assayed AA and CP with the WPC diet compared with the ESBM diet (Table 6). However, we

Table 4. Amount of ileal digesta collected, digesta $\mathrm{pH}$, and parameters of the model for daily $\mathrm{pH}$ fluctuation

\begin{tabular}{|c|c|c|c|c|c|c|c|c|}
\hline \multirow[b]{2}{*}{ Item } & \multicolumn{3}{|c|}{$\operatorname{Diet}^{1}$} & \multirow[b]{2}{*}{ SEM } & \multicolumn{3}{|c|}{$P$-value } & \multirow{2}{*}{$\begin{array}{l}\text { WPC vs. } \\
\text { ESBM }^{2}\end{array}$} \\
\hline & WPC & ESBM & NFree & & Diet & Hour & Diet $\times$ hour & \\
\hline Flow of digesta DM, g/kg of DMI & $223^{\mathrm{c}}$ & $291^{\mathrm{b}}$ & $536^{\mathrm{a}}$ & 16 & $<0.01$ & - & - & $<0.01$ \\
\hline \multicolumn{9}{|l|}{ Digesta collected $^{3}$} \\
\hline Fresh weight, kg & $1.02^{\mathrm{b}}$ & $1.44^{\mathrm{b}}$ & $3.45^{\mathrm{a}}$ & 0.27 & $<0.01$ & - & - & 0.22 \\
\hline Dry weight, g & $114^{\mathrm{b}}$ & $159^{\mathrm{ab}}$ & $203^{\mathrm{a}}$ & 21 & 0.01 & - & - & 0.13 \\
\hline DM, $\%$ & $11.23^{\mathrm{a}}$ & $11.25^{\mathrm{a}}$ & $5.84^{\mathrm{b}}$ & 0.57 & $<0.01$ & - & - & 0.93 \\
\hline $\mathrm{pH}^{4}$ & $7.41^{\mathrm{c}}$ & $7.30^{\mathrm{b}}$ & $7.74^{\mathrm{a}}$ & 0.06 & $<0.01$ & 0.01 & $<0.01$ & $<0.01$ \\
\hline Area above the curve & $-2.97^{\mathrm{ab}}$ & $-4.10^{\mathrm{b}}$ & $-0.23^{\mathrm{a}}$ & 1.30 & 0.05 & - & - & 0.18 \\
\hline \multicolumn{9}{|l|}{$\mathrm{pH}$ model parameters ${ }^{6}$} \\
\hline Initial pH & 6.81 & 7.33 & - & 0.38 & 0.19 & - & - & - \\
\hline First positive slope, $\mathrm{pH} / \mathrm{h}$ & 0.60 & 0.15 & - & 1.89 & 0.08 & - & - & - \\
\hline Time at first knot, $\mathrm{h}$ & 2.05 & 2.69 & - & 0.79 & 0.35 & - & - & - \\
\hline Negative slope, $\mathrm{pH} / \mathrm{h}$ & $-0.86^{\mathrm{b}}$ & $-0.32^{\mathrm{a}}$ & - & 0.25 & 0.05 & - & - & - \\
\hline Time at second knot, h & $6.25^{\mathrm{b}}$ & $8.57^{\mathrm{a}}$ & - & 0.58 & 0.01 & - & - & - \\
\hline Second positive slope, $\mathrm{pH} / \mathrm{h}$ & 0.40 & 0.33 & - & 0.07 & 0.34 & - & - & - \\
\hline
\end{tabular}

${ }^{\mathrm{a}-\mathrm{c}}$ Least squares means within a row with different superscripts are different $(P<0.05)$ with the Tukey-Kramer adjustment.

${ }^{1}$ Calves were fed a whey-based (WPC), enzyme-treated soy-based (ESBM), or N-free milk replacer $2 \times$ daily for $5 \mathrm{~d}$ at a rate of $2 \%$ of BW (DM basis).

${ }^{2} P$-value for the contrast between the WPC and ESBM diets.

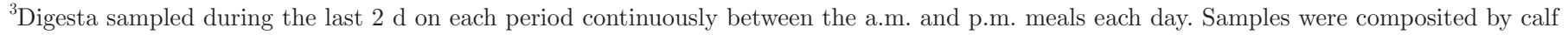
and period.

${ }^{4}$ Least squares means of digesta $\mathrm{pH}$ measured in each sample collected on each period.

${ }^{5}$ Calculated with the trapezoid method using the first $\mathrm{pH}$ value on each collection day as a baseline pH to create the successive trapezoids.

${ }^{6}$ Differences of model parameters between the WPC and ESBM diets were tested by performing a $t$-test to evaluate the significance of a dummy variable that represents the difference between treatments on each particular parameter estimate. Hour represents time postfeeding in hours. 
Table 5. Apparent ileal digestibility of OM, fatty acids, sugars, ash, calcium, and phosphorus

\begin{tabular}{|c|c|c|c|c|c|c|}
\hline \multirow[b]{2}{*}{ Item } & \multicolumn{3}{|c|}{ Diet $^{1}$} & \multirow[b]{2}{*}{ SEM } & \multicolumn{2}{|r|}{$P$-value } \\
\hline & WPC & ESBM & NFree & & $\operatorname{Diet}^{2}$ & WPC vs. $\mathrm{ESBM}^{3}$ \\
\hline $\mathrm{OM}$ & $84.6^{\mathrm{a}}$ & $77.7^{\mathrm{b}}$ & $56.3^{\mathrm{c}}$ & 1.6 & $<0.01$ & $<0.01$ \\
\hline Fatty acids & $90.4^{\mathrm{a}}$ & $89.9^{\mathrm{a}}$ & $39.0^{\mathrm{b}}$ & 1.8 & $<0.01$ & 0.84 \\
\hline Fructose ${ }^{4}$ & $90.5^{\mathrm{a}}$ & $86.2^{\mathrm{a}}$ & $38.8^{\mathrm{b}}$ & 4.5 & $<0.01$ & 0.35 \\
\hline Glucose $^{5}$ & $99.3^{\mathrm{a}}$ & $99.4^{\mathrm{a}}$ & $93.2^{\mathrm{b}}$ & 0.5 & $<0.01$ & 0.85 \\
\hline Sucrose & $70.3^{\mathrm{a}}$ & $59.6^{\mathrm{b}}$ & $71.2^{\mathrm{a}}$ & 3.2 & $<0.01$ & $<0.01$ \\
\hline Lactose & $99.6^{\mathrm{a}}$ & $99.6^{\mathrm{a}}$ & $92.4^{\mathrm{b}}$ & 0.9 & $<0.01$ & 0.98 \\
\hline Maltose & $92.6^{\mathrm{a}}$ & $75.7^{\mathrm{b}}$ & $60.2^{\mathrm{b}}$ & 2.9 & $<0.01$ & 0.01 \\
\hline Ash & $-18.6^{\mathrm{a}}$ & $-20.8^{\mathrm{a}}$ & $-66.6^{\mathrm{b}}$ & 13.3 & $<0.01$ & 0.79 \\
\hline $\mathrm{Ca}$ & $38.1^{\mathrm{a}}$ & $38.1^{\mathrm{a}}$ & $11.5^{\mathrm{b}}$ & 3.9 & $<0.01$ & 0.99 \\
\hline $\mathrm{P}$ & $50.8^{\mathrm{a}}$ & $49.7^{\mathrm{a}}$ & $30.0^{\mathrm{b}}$ & 2.4 & $<0.01$ & 0.65 \\
\hline $\mathrm{Cu}$ & 4.85 & 4.52 & 5.13 & 10.30 & 0.99 & 0.97 \\
\hline $\mathrm{Fe}$ & $-140^{\mathrm{ab}}$ & $-166^{\mathrm{b}}$ & $-90^{\mathrm{a}}$ & 23 & $<0.01$ & 0.18 \\
\hline $\mathrm{Zn}$ & $-124^{\mathrm{a}}$ & $-203^{\mathrm{b}}$ & $-127^{\mathrm{a}}$ & 16 & $<0.01$ & $<0.01$ \\
\hline $\mathrm{Mn}$ & $-27.6^{\mathrm{b}}$ & $-55.5^{\mathrm{c}}$ & $-11.8^{\mathrm{a}}$ & 4.4 & $<0.01$ & $<0.01$ \\
\hline $\mathrm{NDF}^{6}$ & - & 21.7 & - & 33.4 & - & - \\
\hline
\end{tabular}

$\overline{{ }^{a-c} \text { Least squares means within a row with different superscripts are different }(P<0.05) \text { with the Tukey-Kramer }}$ adjustment.

${ }^{1}$ Calves were fed a whey-based (WPC), enzyme-treated soy-based (ESBM), or N-free milk replacer $2 \times$ daily for $5 \mathrm{~d}$ at a rate of $2 \%$ of $\mathrm{BW}$ (DM basis).

${ }^{2} P$-value for the difference in apparent ileal digestibility between the WPC, ESBM, and NFree diets.

${ }^{3} P$-value for the contrast between the WPC and ESBM diets.

${ }^{4}$ Digestibility was calculated using an intake calculated by adding half the concentration of digested sucrose to the analyzed free fructose in the feed.

${ }^{5}$ Digestibility was calculated using an estimated intake by adding half the concentration of digested sucrose and lactose plus all the digested maltose to the analyzed free glucose in the feed.

${ }^{6}$ Flows of NDF during ESBM were adjusted by subtracting the flow of NDF during WPC, before calculations of apparent ideal digestibility.

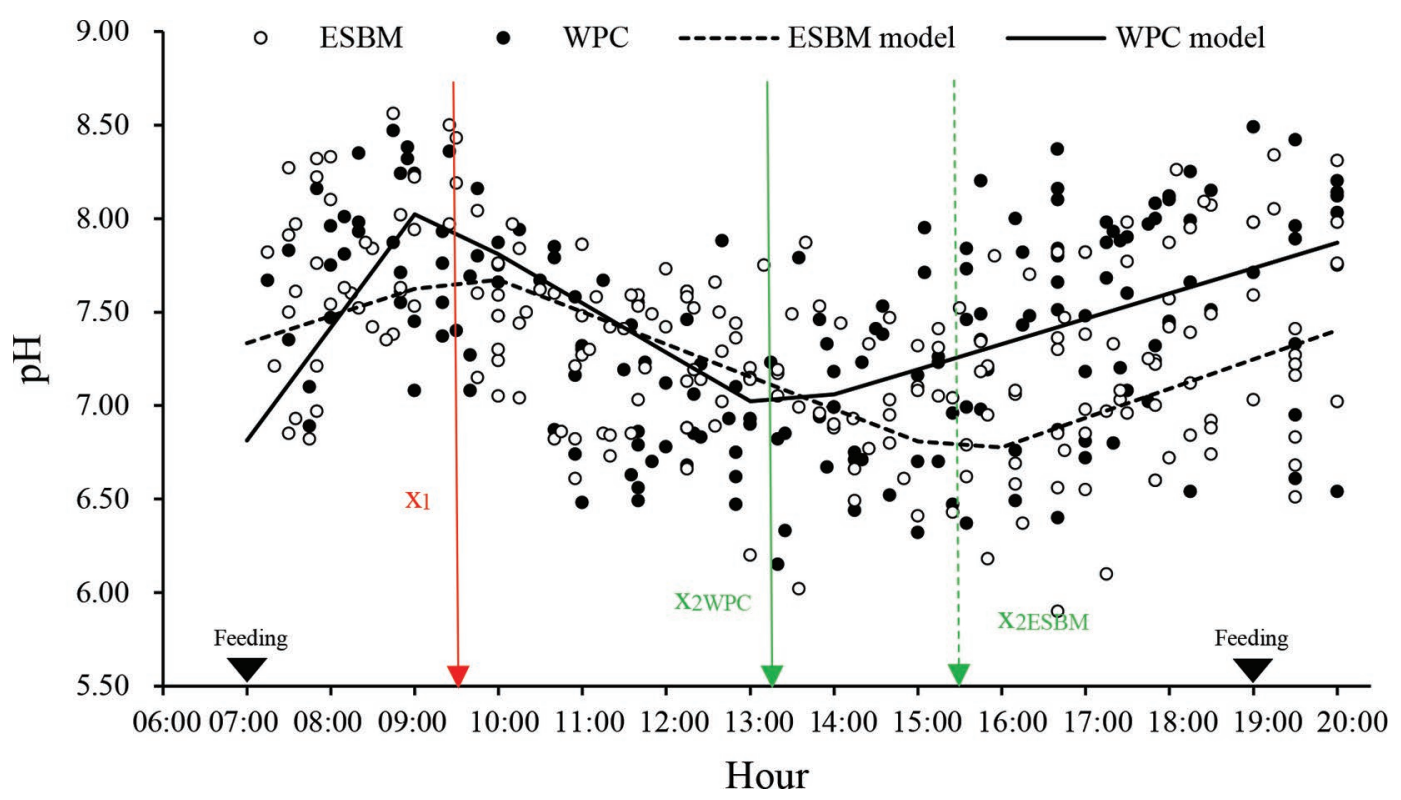

Figure 1. Ileal digesta $\mathrm{pH}$ fluctuation between the morning and evening feedings $(\mathbf{\nabla})$ on 2 consecutive days at the end of each 5-d experimental period. Calves were fed an either whey-based (WPC; $\bullet$ ) or enzyme-treated soy-based (ESBM; $\bigcirc)$ milk replacer $2 \times$ daily for $5 \mathrm{~d}$ at a rate of $2 \%$ of $\mathrm{BW}$ (DM basis). Least squares means of $\mathrm{pH}$ by calf and hour were used to find the best model. The LSM for both diets were fitted according to the following equation: $\mathrm{pH}=\left[\mathrm{b}_{1} \times \max (0\right.$, time $\left.)\right]+\left[\mathrm{b}_{2} \times \max \left(0\right.\right.$, time $\left.\left.-\mathrm{x}_{1}\right)\right]+\left\{\mathrm{a}_{0}+\left[\mathrm{b}_{3} \times \max \left(0\right.\right.\right.$, time $\left.\left.\left.-\mathrm{x}_{2}\right)\right]\right\}$, where $\mathrm{a}_{0}$ is the estimate of initial $\mathrm{pH}, \mathrm{b}_{1}$ and $\mathrm{b}_{3}$ are the 2 positive slopes and $\mathrm{b}_{2}$ is the negative slope, $\mathrm{x}_{1}$ and $\mathrm{x}_{2}$ are the estimates of the time points where a significant change in slope occurred (knots), and time is the hour after feeding the morning meal. This equation explained 84.9 and $90.4 \%$ of the variation for ESBM and WPC, respectively. 
Table 6. Apparent (AID), standard (SID), and true (TID) ileal digestibility of CP and $\mathrm{AA}^{1}$

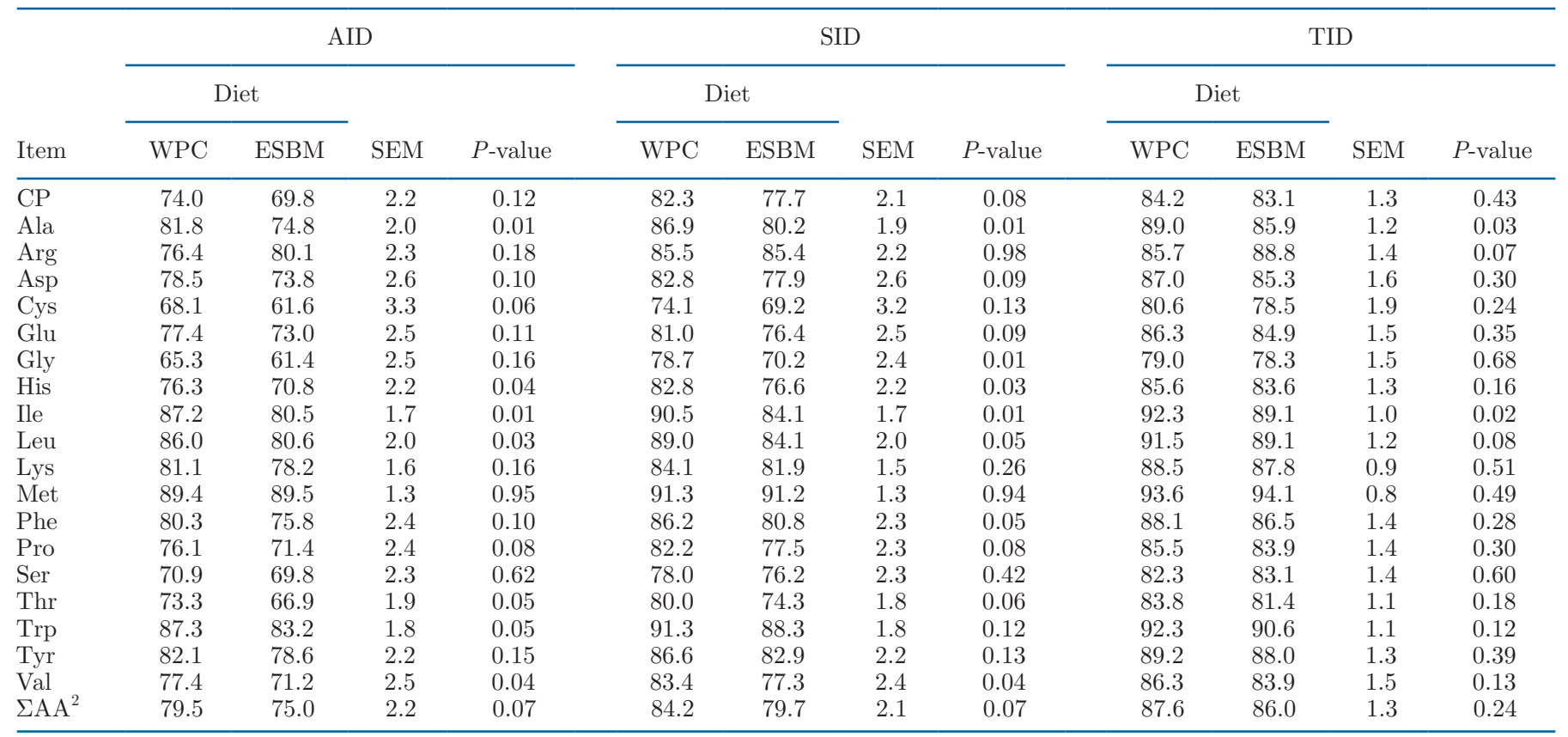

${ }^{1}$ Calves were fed an either whey-based (WPC) or enzyme-treated soy-based (ESBM) milk replacer $2 \times$ daily for $5 \mathrm{~d}$ at a rate of $2 \%$ of BW (DM basis).

${ }^{2}$ Sum of all the assayed AA.

found no differences between diets for TID. Apparent ileal digestibility for most AA was greater (Ala, His, Ile, Leu, Thr, Trp, and Val) or tended to be greater (Asp, Cys, Glu, Phe, and Pro) with the WPC diet than with the ESBM diet. Similarly, SID was greater (Ala, Gly, His, Ile, Leu, Phe, and Val) or tended to be greater (Asp, Glu, Pro, Thr) with the WPC diet for the vast majority of AA. However, when comparing TID, only Ala $(P=0.03)$ and Ile $(P=0.02)$ were higher, and Leu tended $(P=0.08)$ to have higher TID, with the WPC diet compared with the ESBM diet. On the other hand, we detected a tendency $(P=0.07)$ for a lower TID of Arg with the WPC diet compared with the ESBM diet.

\section{Flows of Dietary and Endogenous Proteins}

Flows of AA (13.99 g/ $\mathrm{kg}$ of DMI) and CP (22.43 g/ $\mathrm{kg}$ of DMI) as measured with the NFree diet represented the END basal and were assumed to be constant and invariable across diets (Table 7). Coefficients derived from the multivariate regression analysis estimated that the basal endogenous protein flow comprised protein from the host and gut bacteria in a 50:50 ratio (Figure 2). With the WPC diet, no bacterial protein flow was detected and $\mathrm{END}_{\text {total }}$ was estimated to be $39 \%$ of the total flow of CP. In contrast, total ileal output of protein comprised $16 \%$ with bacterial origin and $28 \%$ from the host when calves were fed the
ESBM diet (Figure 2). Estimated flows of endogenous CP from the host tended $(P=0.10)$ to be lower with the ESBM diet. However, flows of $\mathrm{END}_{\text {total }}$ of $\mathrm{CP}$ and AA were higher with the ESBM diet, whereas flows of undigested dietary protein were no different compared with the WPC diet (Table 7).

\section{DNA and Total Crude Mucin}

Total concentration (Table 8) and flow of DNA were greater with the NFree diet than with the other 2 diets. However, calves fed ESBM showed a greater concentration $(P=0.02)$ and flow $(P<0.01)$ of DNA than those fed WPC. Concentration of crude mucin per digesta DM was smaller with NFree than with the other diets, but it was not different when expressed per unit of digesta CP. Ileal output of crude mucin $(\mathrm{g} / \mathrm{kg}$ of DMI) was smaller with NFree than with the other 2 diets. However, it tended to be greater $(P=0.08)$ with ESBM compared with WPC.

\section{DISCUSSION}

The $\mathrm{pH}$ of digesta in the abomasum increases rapidly after suckling and then decreases until again reaching preprandial values in the 7 to $9 \mathrm{~h}$ after feeding (Constable et al., 2005; Burgstaller et al., 2017). Secretion products (bile, pancreatic juice, and Brunner's juice) 
Table 7. Flows of basal and total (basal + specific) endogenous protein at the ileum (g/kg of DMI)

\begin{tabular}{|c|c|c|c|c|c|}
\hline \multirow[b]{3}{*}{ Item } & \multirow[b]{3}{*}{ Basal $^{1}$} & \multicolumn{4}{|c|}{ Total $^{2}$} \\
\hline & & \multicolumn{2}{|c|}{ Diet $^{3}$} & \multirow[b]{2}{*}{ SEM } & \multirow[b]{2}{*}{$P$-value ${ }^{4}$} \\
\hline & & WPC & ESBM & & \\
\hline $\mathrm{CP}$ & 22.43 & 28.20 & 37.15 & 2.48 & 0.01 \\
\hline Ala & 0.74 & 1.07 & 1.51 & 0.12 & 0.01 \\
\hline Arg & 0.76 & 0.78 & 1.21 & 0.10 & 0.01 \\
\hline Asp & 1.42 & 2.85 & 3.83 & 0.36 & 0.02 \\
\hline Cys & 0.53 & 1.12 & 1.13 & 0.11 & 0.86 \\
\hline Glu & 1.71 & 4.31 & 5.80 & 0.49 & 0.02 \\
\hline Gly & 0.77 & 0.80 & 1.46 & 0.07 & $<0.01$ \\
\hline His & 0.40 & 0.58 & 0.85 & 0.06 & $<0.01$ \\
\hline Ile & 0.58 & 0.90 & 1.36 & 0.12 & 0.01 \\
\hline Leu & 1.07 & 2.02 & 2.54 & 0.28 & 0.11 \\
\hline Lys & 0.90 & 2.24 & 2.29 & 0.18 & 0.83 \\
\hline Met & 0.15 & 0.36 & 0.41 & 0.05 & 0.23 \\
\hline Phe & 0.67 & 0.90 & 1.40 & 0.12 & 0.01 \\
\hline Pro & 0.87 & 1.35 & 1.75 & 0.13 & 0.02 \\
\hline Ser & 0.77 & 1.26 & 1.55 & 0.11 & 0.03 \\
\hline Thr & 0.98 & 1.53 & 1.78 & 0.12 & 0.10 \\
\hline Trp & 0.29 & 0.36 & 0.41 & 0.05 & 0.33 \\
\hline Tyr & 0.43 & 0.69 & 0.92 & 0.09 & 0.03 \\
\hline Val & 0.96 & 1.45 & 1.93 & 0.17 & 0.02 \\
\hline$\Sigma \mathrm{AA}^{5}$ & 13.99 & 24.57 & 32.13 & 2.67 & 0.03 \\
\hline \multicolumn{6}{|c|}{$\begin{array}{l}{ }^{1} \text { Basal endogenous flow of protein in calves fed an N-free milk replacer } 2 \times \text { daily for } 5 \mathrm{~d} \text { at a rate of } 2 \% \text { of } \mathrm{BW} \\
\text { (DM basis). }\end{array}$} \\
\hline \multicolumn{6}{|c|}{$\begin{array}{l}{ }^{2} \text { Total (basal }+ \text { specific) endogenous flow of protein. Flows were estimated applying the percentages obtained } \\
\text { by multiple regression analysis and chi-squared distance according to Duvaux et al. (1990; Figure } 2 \text { ). }\end{array}$} \\
\hline \multicolumn{6}{|c|}{$\begin{array}{l}{ }^{3} \text { Calves were fed an either whey-based (WPC) or enzyme-treated soy-based (ESBM) milk replacer } 2 \times \text { daily for } \\
5 \mathrm{~d} \text { at a rate of } 2 \% \text { of BW (DM basis). }\end{array}$} \\
\hline \multicolumn{6}{|c|}{${ }^{4} P$-value for the difference in total endogenous flow of protein between the WPC and ESBM diets. } \\
\hline
\end{tabular}

are released into the distal duodenum to counteract that acidity (van't Klooster et al., 1969). Therefore, digesta $\mathrm{pH}$ increases gradually along the small intestine, with a change from acid to alkaline near the middle of the jejunum (Mylrea, 1966). Even though pH fluctuations are more attenuated at the ileum, $\mathrm{pH}$ still reflects the changes occurring at the duodenum (Mylrea, 1966). Unlike the other diets, the NFree diet did not seem to induce a significant gastric acid secretion because the $\mathrm{pH}$ values at the ileum did not vary after feeding. Despite the numerous factors involved in regulation of gastric acid secretion (Hersey and Sachs, 1995), ingestion of protein, or more specifically bioavailable protein (Ternouth and Roy, 1973), seems to play a significant role because in the absence of digestible protein there is no need for pepsin activation, which occurs at a $\mathrm{pH}$ of 1.8 to 3.5 (Samloff, 1971).

Similar to what we have observed in the ileum, others have reported that digesta $\mathrm{pH}$ in the duodenum decreases at a faster rate when milk proteins are fed (Colvin et al., 1969; Smith and Sissons, 1975) because of the higher stimulus for acid secretion compared with soy proteins (Williams et al., 1976). Furthermore, in addition to digesta $\mathrm{pH}$ decreasing at a slower rate dur- ing ESBM, it reached a lower postprandial minimum and at a later time than when the WPC diet was fed. The still-possible presence of protease inhibitors in the soy-based MR could have reduced the capacity for $\mathrm{pH}$ regulation by the acinar-ductal units of the exocrine pancreas (Hegyi et al., 2011). In addition, the transformation of carbohydrates present in ESBM into VFA by intestinal bacteria could have contributed to the lower digesta pH (Guilloteau et al., 1986). Even though digesta $\mathrm{pH}$ and flow seem to follow similar patterns after a meal (Kyuma et al., 1979), that relationship does not allow us sufficient precision to explain a difference in abomasal emptying rate (Gaudreau and Brisson, 1980). However, if we assume that the movement of digesta through the small intestine was the same for both diets, ileal digesta $\mathrm{pH}$ would have followed a similar fluctuation as duodenal digesta $\mathrm{pH}$. We then could roughly estimate the relative abomasal emptying rate by measuring the time that digesta $\mathrm{pH}$ needed to reach its nadir once it began to decline from its initial baseline $\left(\mathrm{a}_{0}\right.$; Constable et al., 2006). Following this assumption, gastric emptying when calves were fed $\operatorname{ESBM}\left(\mathrm{x}_{2}-\mathrm{x}_{1}\right.$ $=5.9 \mathrm{~h}$ ) would have been slower than when they were fed WPC $\left(\mathrm{x}_{2}-\mathrm{x}_{1}=4.2 \mathrm{~h}\right)$. Because the whey proteins 
Table 8. The DNA and mucin protein concentrations in digesta at the ileum

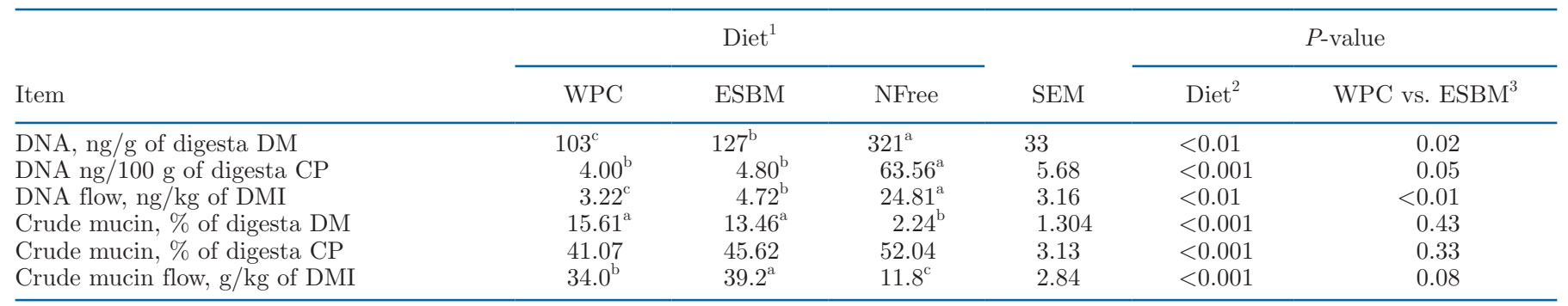

${ }^{\mathrm{a}-\mathrm{c}}$ Least squares means within a row with different superscripts are different $(P<0.05)$ with the Tukey-Kramer adjustment.

${ }^{1}$ Calves were fed a whey-based (WPC), enzyme-treated soy-based (ESBM), or N-free (NFree) milk replacer $2 \times$ daily for $5 \mathrm{~d}$ at a rate of $2 \%$ of BW (DM basis).

${ }^{2} P$-value for the difference in apparent ileal digestibility between the WPC, ESBM, and NFree diets.

${ }^{3} P$-value for the contrast between the WPC and ESBM diets.

present in either MR should have behaved in the same way in both diets, the possible delayed abomasal emptying with the ESBM diet would have occurred only because of the presence of the soy proteins. Gaudreau and Brisson (1980) postulated that the delay could be caused by a temporary "settling" of the soy proteins before release into the duodenum due to their lower solubility compared with whey proteins.

As expected, due to the higher osmolality in the NFree diet because of the large concentration of lactose, calves incurred nutritionally induced diarrhea caused by osmotic imbalance (Brooks et al., 1996). Glucose is linked with $\mathrm{Na}$ for absorption, and consequently water is drawn from the extracellular space into the intestine to compensate for the osmotic imbalance induced by the elevated $\mathrm{Na}$ concentration in the lumen (Michell, 1998). Because this likely was strictly nutritionally induced diarrhea, the immune system did not trigger a reduction in appetite or water intake (Plata-Salamán and Ffrench-Mullen, 1992; Johnson, 1998) and calves voluntarily increased their intake of water. Therefore, the BW loss observed in calves during the NFree diet must be mostly attributed to a loss of skeletal and muscle growth. Although the effect on growth was not

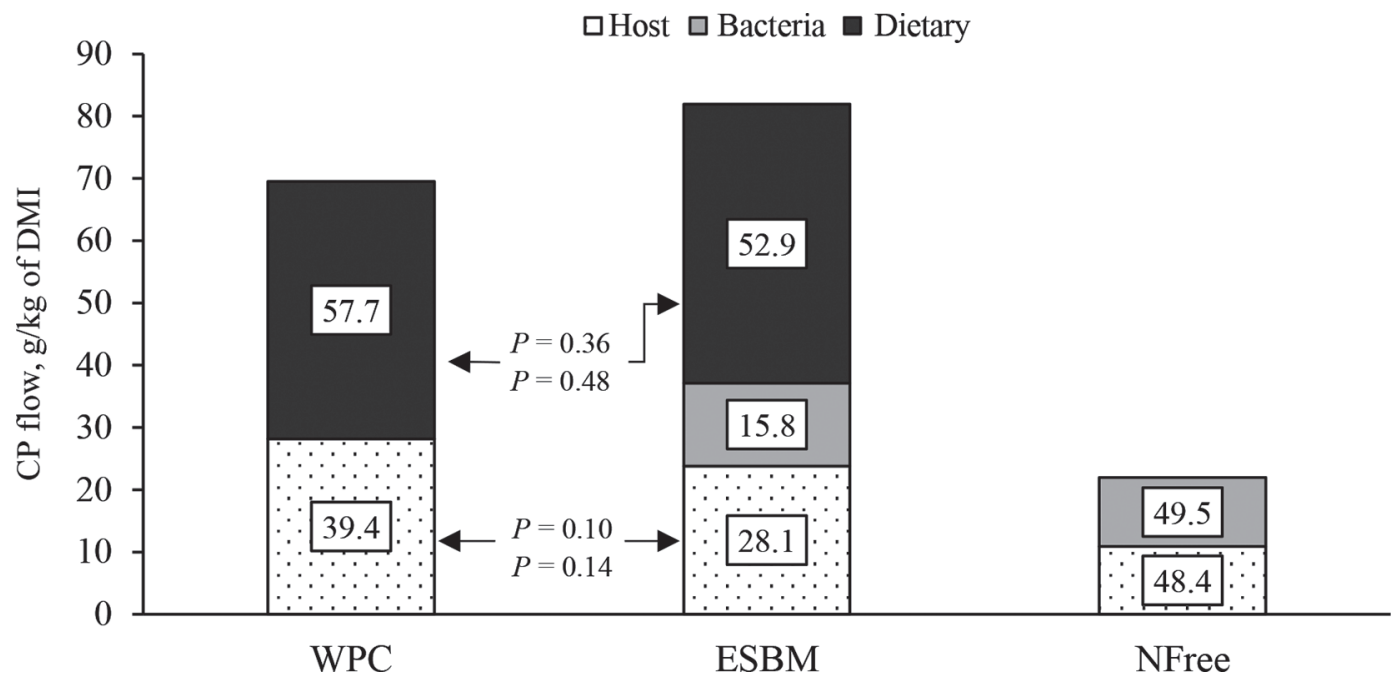

Figure 2. Estimated flow (g/kg of DMI) of dietary protein, and basal (nonspecific) and specific endogenous protein from the host (calf) and bacteria at the ileum. The flow of basal endogenous protein was assumed to be constant and independent of the diet, and it was measured by collection of the digesta from calves fed an N-free milk replacer $2 \times$ daily for $5 \mathrm{~d}$ at a rate of $2 \%$ of BW (DM basis). The flow of total endogenous protein and the relative percentages by origin were estimated using multiple regression analysis and chi-squared distance according to Duvaux et al. (1990). The mean AA profile of axenic lamb feces (Combe, 1976) and calf meconium (Grongnet et al., 1981) was used as a reference for the endogenous protein from the calf (host endogenous), and the mean AA composition of pig (Mason et al., 1975) and sheep (Mason, 1978) fecal bacteria was used as a reference for endogenous bacterial protein. Numbers within each section of the bar represent the estimated percentage of inclusion of that particular protein within the total flow of protein for each diet (WPC = whey-based milk replacer; ESBM $=$ enzyme-treated soy-based milk replacer; NFree = nitrogen-free milk replacer). Numbers between columns represent the $P$-values for the comparison of dietary (solid bars) and endogenous host (dotted bars) protein flow for CP (top $P$-value) and AA (bottom $P$-value) between WPC and ESBM diets. 
the focus of this experiment and the short periods necessitate caution in interpreting differences, the advantage of the ESBM diet in terms of body frame growth deserves further attention as an enhancer of growth and development (Kiers et al., 2003; Senevirathne et al., 2017).

Protein source seems to have not affected digestibility of lactose or glucose, which confirms that degradation of lactose by intestinal lactase is very stable (SteinhoffWagner et al., 2014). In agreement with the literature, disappearance of maltose, fructose, and sucrose was low compared with glucose and lactose (Siddons et al., 1969), especially during the NFree diet. Despite a smaller AID of maltose and sucrose with the ESBM diet compared with the WPC diet, there is not a reason to foresee diminishing effects in growth and development because of the very low concentration of these disaccharides in the diets. Nevertheless, further research is needed to evaluate the effect of these sugars on large intestine fermentation. Even though calves with diarrhea still have a substantial absorptive capacity for glucose (Bywater, 1977), the osmotic imbalance caused by the NFree diet likely reduced the absorptive capacity for all sugars and the other non-nitrogenous components of the diet. Most probably, the damage caused to the intestinal mucosa barrier (Wilms et al., 2019) or the higher rates of passage (Petit et al., 1989) might have diminished the capacity of the intestine for absorption.

Negative values for AID of ash indicate that the outflow at the ileum was bigger than the intake from MR. Even though a net outflow of minerals may be found at the beginning of the small intestine due to endogenous secretions by the gut and pancreas, part of the minerals should have been absorbed before reaching the ileum (Montagne et al., 2001). Pancreatic secretions contain important amounts of macro- and trace minerals, but data on mineral composition and total output are still scarce (Chavez et al., 1997). In pigs, $\mathrm{Ca}$ is the macromineral with the greater presence, followed by P. Among the trace minerals, $\mathrm{Zn}$ is by far the most important followed by Fe. Only Na and Zn seem to have a greater daily output relative to intake that would be capable of affecting metabolism or apparent digestibility (Chavez et al., 1997). However, there are substantial differences, at least in volume and protease concentration, between pancreatic juice of calves and pigs (Ternouth and Roy, 1973; Khorasani et al., 1989; Thaela et al., 1995) that make it difficult to extrapolate similarities in mineral content. The low levels of phytic acid $(0.4 \pm 0.05 \%)$ present in the enzyme-treated soybean meal should have reduced any possible direct or carryover effect on the increase in endogenous mineral secretions by the intestine and pancreas (Woyengo et al., 2009).
During this experiment, calves were bedded with sand instead of straw to avoid the ingestion of fiber to minimize rumen development and avoid the effect of rumen fermentation on degradation and synthesis of AA. Calves were observed licking sand (a common pica symptom) on numerous occasions, which could have contributed to the positive mineral outflow. Despite the high plane of nutrition offered that met feeding recommendations for minerals (NRC, 2001), the lack of solid food intake may have stimulated behavioral licking and subsequent consumption of sand. Even though the intake of soil does not affect nutrient digestibility directly (Miller et al., 1977), not knowing the exact mineral intake from the sand precludes us from fairly evaluating mineral digestibility. Digestibility of Ca and P is usually very high in young milk-fed calves (Guilloteau et al., 1980). However, it decreases with age (Smith, 1969; Hill et al., 2016a), which places our results at least within an expected range. Nevertheless, the probable presence of those minerals in the sand makes any conclusion unreliable. Trace minerals are of vital importance early in the life of a dairy calf (Teixeira et al., 2014), and therefore more research is needed to fine-tune requirements from real ileal digestibilities, which according to our results are low and may be difficult to calculate due to the endogenous secretions.

Milk proteins are virtually fully digested at the end of the ileum (Guilloteau et al., 1986; Montagne et al., 2000b) but not completely (Sedgman et al., 1985). However, the apparent (74 and $79.5 \%$ ) and even true $(84.2$ and $87.6 \%$ ) ileal digestibility values for $\mathrm{CP}$ and AA, respectively, obtained in this study for WPC differ substantially from those found in the literature (Caugant et al., 1993; Kanjanapruthipong, 1998). The differences in experimental design, such as the sample collection method and the feeding frequency and rate, compared with other similar experiments may have contributed to our lower digestibility values because at least different levels of protein intake do not affect $\mathrm{N}$ digestibility (Montagne et al., 2000b). As demonstrated by Hill et al. (2010), total-tract apparent digestibility was lower when feeding a greater $(1.6 \times)$ dose of MR, most probably due to faster transit across the gastrointestinal tract (Smith, 1963). According to the literature, only Montagne et al. (2000b, 2001, 2003) fed MR $\left(55 \mathrm{~g}\right.$ of $\mathrm{DM} / \mathrm{kg}$ of $\left.\mathrm{BW}^{0.75}\right)$ at a dose similar to ours. However, those authors infused the reconstituted diets continuously through an abomasal catheter and even added sodium citrate to avoid clogging, to obtain a slow and continuous transit across the digestive tract. Nevertheless, AID values for total and individual AA with a milk protein-based MR were higher overall than those reported by Khorasani et al. (1989), who used a sampling procedure similar to ours. 
It might be argued that physiological reactions to the higher osmolality of the NFree diet could have affected our estimates of $\mathrm{END}_{\text {basal }}$. However, the $\mathrm{END}_{\text {basal }}$ of $\mathrm{CP}$ and $\mathrm{AA}$ is in agreement with that $(20$ and $12 \mathrm{~g} /$ $\mathrm{kg}$ of DMI, respectively) reported by Montagne et al. (2000b). Furthermore, we found that digesta collected during NFree equally comprised bacterial and host endogenous protein (50:50) and that only with the ESBM diet was there a relevant amount of endogenous bacterial protein compared with the WPC diet. Other methods available for the determination of $\mathrm{END}_{\text {basal }}$ include feeding a highly digestible purified diet or peptides and the regression technique (Stein et al., 2007). However, feeding a highly digestible diet or peptides would necessitate the assumption that they are totally digested and that endogenous secretions are not stimulated by them, which may result in an overestimation of the basal losses. The regression technique involves the use of a minimum of 3 diets, with a single protein source at different inclusion rates. Even though the AA profile of the $\mathrm{END}_{\text {basal }}$ obtained with this technique is similar to that obtained using an NFree diet, it yields a much greater estimation of AA flow (Montagne et al., 2000b). Based on practicality and to maintain a consistent feeding regimen with the rest of the treatments, the NFree diet technique was selected. However, different strategies to minimize the nutritional diarrhea could be considered for future experiments, such as increasing the number of meals per day or reducing the lactose inclusion. Basal endogenous losses with the NFree diet are influenced by physiological, dietary, and generic factors and are therefore specific to the animals and experimental setting. As suggested for research on pig feed ingredients, $\mathrm{END}_{\text {basal }}$ must be measured routinely when evaluating ileal digestibilities (Stein et al., 2007).

Based on previous analysis, the soy protein source included in the ESBM diet contained only trace amounts of antitrypsin activity $(1.3 \pm 0.5 \mathrm{mg}$ of trypsin units inhibited $/ \mathrm{g})$ and $\beta$-conglycinin $(2.0 \pm 1.0 \mathrm{mg} / \mathrm{kg})$ and was practically free of oligosaccharides, phytic acid, and lectins. Despite the low level of those ANF, the presence of NDF (2.2\%) might have contributed to the secretion of endogenous protein from the small intestine (Montagne et al., 2000c, 2001), thereby explaining the estimated tendencies to higher flow of host endogenous protein and the measured higher flow of crude mucin between diets. Carbohydrates and fiber present in the ESBM also could have stimulated microbial fermentation along the small intestine (Argenzio and Southworth, 1974; Gilbert et al., 2015) and perhaps even in the rumen (Rey et al., 2012) in case some of the milk would fail to bypass it totally (Wise and Anderson, 1939; Abe et al., 1979), which would explain the net outflow of endogenous bacterial protein (Lallès, 1993). Knowledge about gut bacterial density and its interaction with dietary proteins and their implications in intestinal tract development and function in calves is still limited (Malmuthuge and Guan, 2017). In pigs and humans, there is evidence suggesting microbial utilization of AA in the small intestine. In pathological conditions in which harmful bacteria proliferate, the availability of AA for the host can therefore be reduced and the by-products of protein fermentation can increase local inflammation (Diether and Willing, 2019). On the other hand, a greater bacterial population in the large intestine would increase the synthesis of short-chain fatty acids available for absorption by the colonic epithelium (Diether and Willing, 2019). More research is needed to evaluate the potential benefits or disadvantages of increased flow of bacterial protein in the small and large intestine.

Despite the numerical advantage in AID of milk over soy proteins, we found no significant differences in total AA and CP, similar to what has been reported in the literature (Khorasani et al., 1989; Tukur et al., 1993; Montagne et al., 2001). Like Khorasani et al. (1989), we found no differences for AID of Arg, Gly, Lys, Met, Ser, and Tyr; this is similar to the results of Caugant et al. (1993) with the exception of Ser and Tyr. On the other hand, other authors did find AID values for CP that were significantly lower with soy protein-based MR (Guilloteau et al., 1986; Tukur et al., 1993; Kanjanapruthipong, 1998).

Once corrected by the $\mathrm{END}_{\text {basal }}$, SID of AA increased by approximately $5.5 \%$ on average with respect to AID in both diets. Among all AA, Arg, Cys, Gly, Ser, and Thr had the biggest increases, which implies a larger presence of those AA in endogenous protein secretions. For instance, mucin, which is the main component of gastrointestinal mucus and can represent $19 \%$ of the END $_{\text {total }}$, is rich in Thr, Ser, Gly, and Ala (Montagne et al., 2000c). Regardless of the type of calculation (AID, SID, or TID) or diet, digestibilities of Cys and Gly were the lowest among all AA, which agrees with the literature (Guilloteau et al., 1986; Khorasani et al., 1989; Caugant et al., 1993; Montagne et al., 2001). On the contrary, Met, Ile, Leu, and Trp showed the highest digestibilities among all assayed AA. However, that observation is not extended to other values found in the literature. Unless an increase in endogenous secretion of proteins would have a metabolic effect by the diversion of AA toward the synthesis of endogenous proteins, the lower SID and TID of the AA observed with ESBM are not expected to affect growth and development because none of them are among the most limiting AA for young calves (Hill et al., 2008; Wang et al., 2012). Even 
though we did not detect any short-term reduction in growth, further research is needed to assess long-term effects of these differences.

In agreement with previous studies (Bush et al., 1992; Caugant et al., 1993; Montagne et al., 2001), the differences found in AID and SID of individual AA between milk and soy proteins were mainly due to the higher flow of undigested endogenous proteins. Digestibilities for individual and total AA and $\mathrm{CP}$ with the ESBM diet increased remarkably after being adjusted for $\mathrm{END}_{\text {total }}$. This difference was especially true for those AA with a higher presence in the AA composition of endogenous protein such as Cys, Glu, Gly, Asp, and Thr, among others (Guilloteau et al., 1983; Montagne et al., 2000c). Montagne et al. (2001) reported even bigger differences between MR based on milk or alternative proteins when TID of CP and total AA were compared. In their study, TID of the all-milk diet was virtually complete, but the increase of the TID values for the alternative protein diet was not equipotential.

Values for TID of AA in young preruminant calves in the literature are scarce, and most are derived from estimations. Nevertheless, to our knowledge no AA has reached a greater TID with the alternative protein-based diet and, when comparing AID, no AA has reached a greater numeric value. It is therefore relevant to point out that TID of Arg tended to be higher and that of Met was numerically higher with the ESBM diet than with the WPC diet. Arginine is considered an essential AA in newborns and plays an important role in gastrointestinal and immune function as well as in $\mathrm{N}$ metabolism (Wu et al., 2009). Hill et al. (2011) found no effect on growth or on concentration of assayed blood metabolites during supplementation of MR with Arg to young dairy calves. However, other authors have found that Arg supplementation altered the humoral immune response and increased ADG (Fligger et al., 1997), villus height, villus width, and ratio of globet cells per villus (Van Keulen et al., 2017). Differences in growth were detected only in the study where solid feed was not offered (Fligger et al., 1997), which reflects the bigger role of solid feed as a source of Arg compared with MR (Quigley et al., 1985). Because intestinal mucin is secreted by the goblet cells in the villi to protect the mucosal barrier (Kim and Ho, 2010), the greater concentration of Arg in ESBM and its greater digestibility also could have added to a bigger contribution of mucin to the endogenous protein pool. In addition, other metabolites from Arg metabolism, such as nitric oxide and polyamines, are involved in cell proliferation and turnover in epithelial and vascular endothelial cells by activating the mammalian target of rapamycin pathway (Tan et al., 2010). The role of Arg as the main AA responsible for the overall favorable results of ESBM in terms of digestibility, growth, and health would require further investigation.

According to our results, DNA concentration in digesta seems to be an optimal proxy for comparing endogenous protein content in ileal digesta between different protein sources in MR. Because the DNA extraction method used in this study does not differentiate between bacterial and genomic host DNA, we cannot evaluate the contribution of gut and intestine exfoliated epithelial cells to the final DNA digesta pool (Rosa et al., 2018). The presence of fiber in the ESBM diet may have increased the content of sloughed epithelial cells (Nyachoti et al., 2010). Similarly, total crude mucin determination allowed us to estimate the differences between diets for host endogenous protein flow. Mucin is the main protein within the total endogenous protein mixture from the host. Among other functions, it lubricates and protects mucosal epithelia from physical and infectious damage (Kim and Ho, 2010). Assuming a CP content in calf intestinal mucin of $52.6 \%$ of DM (Montagne et al., 2000c), the basal flow of mucin protein at the ileum as determined by the NFree diet was higher (6 vs. $4 \mathrm{~g} / \mathrm{kg}$ of DMI) than reported previously by Montagne et al. (2000a). The disruption of the mucosal barrier potentially caused by the high osmolality of the NFree (Wilms et al., 2019) may have contributed to a greater epithelial turnover and mucus secretion rate. Enteric pathogenic diarrheas induce a reduction in the number of globet cells (Mebus et al., 1971; Kim and Ho, 2010); however, it is not known whether compensatory turnover mechanisms in epithelial cells would still be active in a healthy calf (Van Bruchem et al., 1997). Indeed, the greater concentrations of DNA and crude mucin concentrations relative to the other 2 diets and the literature, respectively, could be explained by a combined epithelial lining shedding and hypersecretion of mucus (Pearson et al., 1987; Kim and Ho, 2010). Furthermore, an increased epithelial turnover could support bacterial proliferation by increasing the availability of binding sites for bacteria in the small intestine (Pusztai, 1992). Nevertheless, the non-mucin-specific method used in our study may have overestimated mucin protein output (Piel et al., 2004).

Also in close agreement with Montagne et al. (2000a), mucin protein represented $27 \%$ of the total endogenous CP losses. However, unlike those authors, we observed an increase in crude mucin output with higher $\mathrm{CP}$ intake, probably because in our study there was considerable content of undigested dietary proteins reaching the ileum. In addition, we detected an increasing logarithmic relationship between ileal flows of crude mucin and $\mathrm{CP}$ for all diets (Figure 3a), which highlights the 
crucial importance of considering endogenous $\mathrm{N}$ losses to evaluate intestinal or fecal digestibilities of protein (Nyachoti et al., 2010). Nevertheless, the literature regarding the interaction of gastrointestinal mucosa with dietary proteins in the small intestine is limited, and further research is needed to evaluate, for instance,
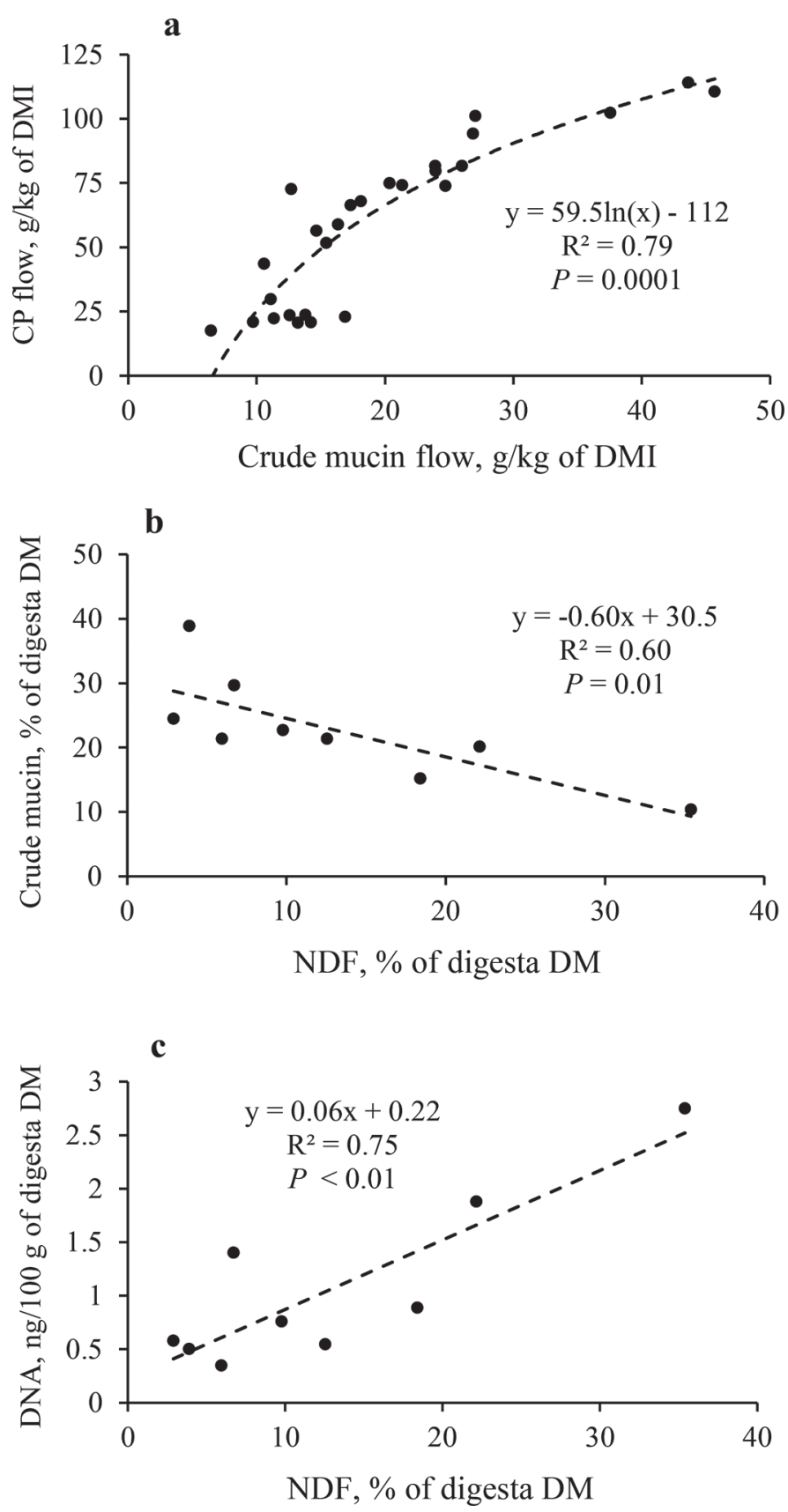

Figure 3. Relationships between the concentrations of crude mucin and $\mathrm{CP}$ in digesta DM (a) and between the concentrations of NDF and crude mucin (b) and DNA (c) for the all-milk milk replacer diet (i.e., the diet with whey protein concentrate as the only source of protein) in ileal digesta $(\mathrm{n}=9)$. the effect of milk proteins on mucin secretion in calves (Steele et al., 2016).

Digestibility of NDF is usually very low in young preweaning calves due to the immaturity of the digestive tract, especially when large amounts of milk or MR are being fed (Hill et al., 2016b). Because usually only total-tract digestibilities are reported, it is important to note that there is extensive fermentation of soluble fiber in the hindgut (Abelilla and Stein, 2019). In addition, in feces and intestinal digesta there are nondietary components that interfere with the analysis of dietary fiber (Montoya et al., 2016). Bacteria and mucin contain some of the same sugar residues present in dietary fiber and therefore are the main sources of interference in digesta. In our study, microbial protein seemed to be interfering with analysis of NDF but not that of crude mucin. We found a positive linear relationship between NDF and DNA concentration in digesta (Figure 3.c) but a negative relationship between NDF and crude mucin content (Figure 3.b) with the WPC diet, where there was no effect of dietary fiber from the soy or excessive epithelial shedding by the induced diarrhea in NFree (Kim and Ho, 2010). Even after adjustment of the ileal flows of NDF during ESBM with the "basal" flows found with the WPC diet, our results emphasize the relatively low ileal digestibilities of NDF during the preweaning period.

Despite the short experimental periods, the ESBM diet resulted in increased fecal consistency and slightly improved respiratory health scores (nasal discharge). Improved overall health and fecal scores also were found by Kim et al. (2012) in calves fed a fungaltreated soybean meal compared with calves fed regular soybean meal. These effects might be attributed to the release of bioactive peptides and other compounds by enzymatic hydrolysis during the manufacturing process (Chatterjee et al., 2018). Nevertheless, because digesta DM percentage at the ileum did not differ between WPC and ESBM, the different fecal scores could probably be due to a higher content of endogenous protein secretions (mucin) or to a higher absorption rate of water at the large intestine because of better villous or crypt epithelium integrity (Berg, 1981). The greater bacterial flow may have contributed by increasing the availability of short-chain fatty acids for epithelial cell growth and proliferation.

\section{CONCLUSIONS}

Overall, there were no appreciable differences in the AID of the main dietary components and of the TID of most AA and CP between MR. The slight disadvantage in $\mathrm{CP}$ and $\mathrm{AA}$ apparent digestibility with the ESBM diet disappeared once digesta outflows were corrected 
by the estimated endogenous protein losses. Adjusting digestibilities of $\mathrm{AA}$ in $\mathrm{MR}$ by endogenous losses is crucial when comparing alternative proteins with milk proteins. Differences found between the WPC and ESBM diets for AID of non-N nutrient fractions such as $\mathrm{OM}$ and microminerals can be attributed to the increase in endogenous secretions with soy proteins. However, further research is needed to evaluate the effect of altered endogenous secretions on calf nutrient requirements and on interactions of plant proteins with the gastrointestinal mucosa during extended periods of feeding. Substitution of $50 \%$ of the protein from whey with an enzymatically treated soybean meal did not affect major nutrient digestibility or calf growth and improved fecal consistency during the length of the study. This novel product shows potential as a valuable feed for young calves; however, diet digestibility is only one aspect to look at, and further studies are needed to confirm its long-term use as a replacement for milk proteins.

\section{ACKNOWLEDGMENTS}

Financial support was provided by Hamlet Protein A/S, Horsens, Denmark; Zinpro Corporation, Eden Prairie, MN; and by state and federal funds appropriated to the Illinois Agricultural Experiment Station. The authors have not stated any conflicts of interest.

\section{REFERENCES}

Abe, M., T. Iriki, K. Kondoh, and H. Shibui. 1979. Effects of nipple or bucket feeding of milk-substitute on rumen by-pass and on rate of passage in calves. Br. J. Nutr. 41:175-181. https://doi.org/10 .1079/BJN19790024.

Abelilla, J. J., and H. H. Stein. 2019. Degradation of dietary fiber in the stomach, small intestine, and large intestine of growing pigs fed corn- or wheat-based diets without or with microbial xylanase. J. Anim. Sci. 97:338-352. https://doi.org/10.1093/jas/sky403.

Ansia, I., H. H. Stein, M. R. Murphy, and J. K. Drackley. 2019. Technical note: Establishment of an ileal cannulation technique in preweaning calves and use of a piecewise regression approach to evaluate effects on growth and $\mathrm{pH}$ fluctuation of ileal digesta. J. Dairy Sci. 102:11061-11066. https://doi.org/10.3168/jds.2019-16788.

AOAC International. 2006. Official Methods of Analysis of AOAC International. 18th ed. Assoc. Off. Anal. Chem., Gaithersburg, MD.

Argenzio, R. A., and M. Southworth. 1974. Sites of organic acid production and absorption in gastrointestinal tract of the pig. Am. J. Physiol. 228:454-460.

Berg, I. E. 1981. A pathologist's view of the scouring calf. North Dakota Farm Res. 38:10-12.

Brooks, H. W., D. G. White, A. J. Wagstaff, and A. R. Michell. 1996. Evaluation of a nutritive oral rehydration solution for the treatment of calf diarrhea. Br. Vet. J. 152:699-708. https://doi.org/10 .1016/S0007-1935(96)80123-0.

Burgstaller, J., T. Wittek, and G. W. Smith. 2017. Invited review: Abomasal emptying in calves and its potential influence on gastrointestinal disease. J. Dairy Sci. 100:17-35. https://doi.org/10 $.3168 /$ jds.2016-10949.

Bush, R. S., R. Toullec, I. Caugant, and P. Guilloteau. 1992. Effects of raw pea flour on nutrient digestibility and immune responses in the preruminant calf. J. Dairy Sci. 75:3539-3552. https://doi.org/ 10.3168/jds.S0022-0302(92)78130-2.

Bywater, R. J. 1977. Evaluation of an oral glucose-glycine-electrolyte formulation and amoxicillin for treatment of diarrhea in calves. Am. J. Vet. Res. 38:1983-1987.

Caugant, I., R. Toullec, M. Formal, P. Guilloteau, and L. Savoie. 1993. Digestibility and amino acid composition of digesta at the end of the ileum in preruminant calves fed soybean protein. Reprod. Nutr. Dev. 33:335-347. https://doi.org/10.1051/rnd:19930403.

Cervantes-Pahm, S. K., and H. H. Stein. 2010. Ileal digestibility of amino acids in conventional, fermented, and enzyme-treated soybean meal and in soy protein isolate, fish meal, and casein fed to weanling pigs. J. Anim. Sci. 88:2674-2683. https://doi.org/10 $.2527 /$ jas.2009-2677.

Chatterjee, C., S. Gleddie, and C.-W. Xiao. 2018. Soybean bioactive peptides and their functional properties. Nutrients 10:E1211. https://doi.org/10.3390/nu10091211.

Chavez, E. R., S. Li, and W. C. Sauer. 1997. Mineral contribution of pancreatic secretion in growing pigs fed two dietary protein levels. Pages 319-320 in Proc. 9th Int. Symp. on Trace Elements in Man and Animals. NRC Research Press, Ottawa, ON, Canada.

Chompreeda, P. T., and M. L. Fields. 1984. Effects of heat and natural fermentation on amino acids, flatus producing compounds, lipid oxidation and trypsin inhibitor in blends of soybean and cornmeal. J. Food Sci. 49:563-565. https://doi.org/10.1111/j.1365-2621.1984 .tb12468.x.

Colvin, B. M., R. A. Lowe, and H. A. Ramsey. 1969. Passage of digesta from the abomasum of a calf fed soy flour milk replacers and whole milk. J. Dairy Sci. 52:687-688. https://doi.org/10.3168/jds.S0022 -0302(69)86629-4.

Combe, E. 1976. Influence de la microflore intestinale sur la composition en acides amines des feces des agneaux. C. R. Seances Soc. Biol. Fil. 170:787-793.

Constable, P. D., A. F. Ahmed, and N. A. Misk. 2005. Effect of suckling cow's milk or milk replacer on abomasal luminal $\mathrm{pH}$ in dairy calves. J. Vet. Intern. Med. 19:97-102. https://doi.org/10.1892/ 0891-6640(2005) 19<97:eoscmo > 2.0.co;2

Constable, P. D., T. Wittek, A. F. Ahmed, T. S. Marshall, I. Sen, and M. Nouri. 2006. Abomasal pH and emptying rate in the calf and dairy cow and the effect of commonly administered therapeutic agents. Page 15 in Proc. World Buiatrics Congress, Nice, France.

Diether, N. E., and B. P. Willing. 2019. Microbial fermentation of dietary protein: An important factor in diet-microbe-host interaction. Microorganisms 7:19. https://doi.org/10.3390/ microorganisms7010019.

Drackley, J. K. 2008. Calf nutrition from birth to breeding. Vet. Clin. North Am. Food Anim. Pract. 24:55-86. https://doi.org/10.1016/ j.cvfa.2008.01.001.

Duvaux, C., P. Guilloteau, R. Toullec, and J. W. Sissons. 1990. A new method of estimating the proportions of different proteins in a mixture using amino acid profiles: Application to undigested proteins in the preruminant calf. Ann. Zootech. 39:9-18. https:// doi.org/10.1051/animres:19900102.

Feng, J., X. Liu, Z. R. Xu, Y. P. Lu, and Y. Y. Liu. 2007. Effect of fermented soybean meal on intestinal morphology and digestive enzyme activities in weaned piglets. Dig. Dis. Sci. 52:1845-1850. https://doi.org/10.1007/s10620-006-9705-0.

Fligger, J. M., C. A. Gibson, L. M. Sordillo, and C. R. Baumrucker. 1997. Arginine supplementation increases weight gain, depresses antibody production, and alters circulating leukocyte profiles in preruminant calves without affecting plasma growth hormone concentrations. J. Anim. Sci. 75:3019-3025. https://doi.org/10.2527/ 1997.75113019x.

Gaudreau, J. M., and G. J. Brisson. 1980. Abomasum emptying in dairy calves fed milk replacers with varying fat and sources of protein. J. Dairy Sci. 63:426-440. https://doi.org/10.3168/jds.S0022 -0302(80)82950-X.

Gilbert, M. S., A. J. Pantophlet, H. Berends, A. M. Pluschke, J. J. van den Borne, W. H. Hendriks, H. A. Schols, and W. J. Gerrits. 2015. Fermentation in the small intestine contributes substantially to 
intestinal starch disappearance in calves. J. Nutr. 145:1147-1155. https://doi.org/10.3945/jn.114.208595.

Gro Intelligence. 2017. Can soy protein become the next whey? Accessed Dec. 4, 2018. https://gro-intelligence.com/insights/soy -protein-next-whey-protein.

Grongnet, J. F., P. Patureau-Mirand, R. Toullec, J. Prugnaud, J. N. Nouchet, J. Lareynie, M. Lesage, M.-C. Valluy, and O. Bernard. 1981. Utilisation des proteines du lait du lactoserum par le jeune veau preruminant. Influence de l'age et de la denaturation des proteines du lactoserum. Ann. Zootech. 30:443-464. https://doi.org/ 10.1051/animres:19810405.

Guilloteau, P., R. Toullec, J. F. Grongnet, P. Patureau-Mirand, J. Prugnaud, and D. Sauvant. 1986. Digestion of milk, fish and soyabean protein in the preruminant calf: Flow of digesta, apparent digestibility at the end of the ileum and amino acid composition of ileal digesta. Br. J. Nutr. 55:571-592. https://doi.org/10.1079/ BJN19860063.

Guilloteau, P., D. Sauvant, and P. Patureau-Mirand. 1983. Methods of comparing amino acid composition of proteins: Application to undigested proteins in the preruminant calf. Ann. Nutr. Metab. 27:457-469. https://doi.org/10.1159/000176720.

Guilloteau, P., R. Toullec, M. Beaufils, S. Boussion, J. Lareynie, Y. Manis, and J. N. Nouchet. 1980. Digestion of milk protein and methanol-grown bacteria protein in the preruminant calf. I. Kinetics and balance in the terminal small intestine and faecal balance. Reprod. Nutr. Dev. 20(3A):601-613. https://doi.org/10.1051/rnd: 19800402.

Hegyi, P., J. Maléth, V. Venglovecz, and Z. Rakonczay Jr. 2011. Pancreatic ductal bicarbonate secretion: Challenge of the acinar acid load. Front. Physiol. 2:36. https://doi.org/10.3389/fphys.2011 .00036 .

Hersey, S. J., and G. Sachs. 1995. Gastric acid secretion. Physiol. Rev. 75:155-189. https://doi.org/10.1152/physrev.1995.75.1.155.

Hill, T. M., H. G. Bateman II, J. M. Aldrich, and R. L. Schlotterbeck. 2010. Effect of milk replacer program on digestion of nutrients in dairy calves. J. Dairy Sci. 93:1105-1115. https://doi.org/10.3168/ jds.2009-2458.

Hill, T. M., H. G. Bateman II, J. M. Aldrich, and R. L. Schlotterbeck. 2011. Effects of adding arginine and histidine to dairy calf milk replacers. Prof. Anim. Sci. 27:565-570. https://doi.org/10.15232/ S1080-7446(15)30540-4.

Hill, T. M., H. G. Bateman II, J. M. Aldrich, R. L. Schlotterbeck, and K. G. Tanan. 2008. Optimal concentrations of lysine, methionine, and threonine in milk replacers for calves less than five weeks of age. J. Dairy Sci. 91:2433-2442. https://doi.org/10.3168/jds.2007 -0610 .

Hill, T. M., J. D. Quigley, H. G. Bateman II, F. X. Suarez-Mena, T. S. Dennis, and R. L. Schlotterbeck. 2016a. Effect of milk replacer program on calf performance and digestion of nutrients in dairy calves to 4 months of age. J. Dairy Sci. 99:8103-8110. https://doi .org/10.3168/jds.2016-11239.

Hill, T. M., J. D. Quigley, F. X. Suarez-Mena, H. G. Bateman II, and R. L. Schlotterbeck. 2016b. Effect of milk replacer feeding rate and functional fatty acids on dairy calf performance and digestion of nutrients. J. Dairy Sci. 99:6352-6361. https://doi.org/10.3168/ jds.2015-10812.

Huisman, J., and A. J. M. Jansman. 1991. Dietary effects and some analytical aspects of antinutritional factors in peas (Pisum sativum), common beans (Phaseolus vulgaris) and soybeans (Glycine $\max$ L.) in monogastric farm animals. A literature review. Nutr. Abstr. Rev. Ser. B 61:901-921.

Johnson, R. W. 1998. Immune and endocrine regulation of food intake in sick animals. Domest. Anim. Endocrinol. 15:309-319. https:// doi.org/10.1016/s0739-7240(98)00031-9.

Kanjanapruthipong, J. 1998. Supplementation of milk replacers containing soy protein with threonine, methionine, and lysine in the diets of calves. J. Dairy Sci. 81:2912-2915.

Kay, H. D. 1926. Note on the variation in the end-products of bacterial fermentation resulting from increased combined oxygen in the substrate. Biochem. J. 20:321-329. https://doi.org/10.1042/ bj0200321.
Khorasani, G. R., L. Ozimek, W. C. Sauer, and J. J. Kennelly. 1989. Substitution of milk protein with isolated soy protein in calf milk replacers. J. Anim. Sci. 67:1634-1641. https://doi.org/10.2527/ jas1989.6761634x.

Kiers, J. L., J. C. Meijer, M. J. R. Nout, F. M. Rombouts, M. J. A. Nabuurs, and J. Van Der Meulen. 2003. Effect of fermented soya beans on diarrhoea and feed efficiency in weaned piglets. J. Appl. Microbiol. 95:545-552. https://doi.org/10.1046/j.1365-2672.2003 .02011.x.

Kiers, J. L., A. E. A. Van Laeken, F. M. Rombouts, and M. J. R. Nout. 2000. In vitro digestibility of bacillus fermented soya bean. Int. J. Food Microbiol. 60:163-169. https://doi.org/10.1016/s0168 $-1605(00) 00308-1$.

Kim, M. H., C. H. Yun, H. S. Kim, J. H. Kim, S. J. Kang, C. H. Lee, J. Y. Ko, and J. K. Ha. 2010. Effects of fermented soybean meal on growth performance, diarrheal incidence and immune-response of neonatal calves. Anim. Sci. J. 81:475-481. https://doi.org/10 $.1111 /$ j.1740-0929.2010.00760.x.

Kim, M. H., C. H. Yun, C. H. Lee, and J. K. Ha. 2012. The effects of fermented soybean meal on immunophysiological and stressrelated parameters in Holstein calves after weaning. J. Dairy Sci. 95:5203-5212. https://doi.org/10.3168/jds.2012-5317.

Kim, Y. S., and S. B. Ho. 2010. Intestinal goblet cells and mucins in health and disease: Recent insights and progress. Curr. Gastroenterol. Rep. 12:319-330. https://doi.org/10.1007/s11894-010-0131 -2 .

Kwon, I. H., M. H. Kim, C. H. Yun, J. Y. Go, C. H. Lee, H. J. Lee, W. Phipek, and J. K. Ha. 2011. Effects of fermented soybean meal on immune response of weaned calves with experimentally induced lipopolysaccharide challenge. Asian-Australas. J. Anim. Sci. 24:957-964. https://doi.org/10.5713/ajas.2011.10419.

Kyuma, T., T. Kikuchi, M. Takahashi, and S. Takizawa. 1979. Flow of digesta passing through the duodenum in the naturally suckled calves. Jpn. J. Zootech. Sci. 51:229-232.

Lallès, J. P. 1993. Nutritional and antinutritional aspects of soyabean and field pea proteins used in veal calf production: A review. Livest. Prod. Sci. 34:181-202. https://doi.org/10.1016/0301 -6226(93)90106-R.

Malmuthuge, N., and L. L. Guan. 2017. Understanding the gut microbiome of dairy calves: Opportunities to improve early-life gut health. J. Dairy Sci. 100:5996-6005. https://doi.org/10.3168/jds .2016-12239.

Mason, B. S., and H. T. Slover. 1971. Gas-chromatographic method for the determination of sugars in foods. J. Agric. Food Chem. 19:551-554. https://doi.org/10.1021/jf60175a006.

Mason, V. C. 1979. The quantitative importance of bacterial residues in the non-dietary faecal nitrogen of sheep. Z. Tierphysiol. Tierernahr. Futtermittelkd. 41:131-139. https://doi.org/10.1111/j.1439 -0396.1978.tb00574.x.

Mason, V. C., A. Just, and S. Bech-Andersen. 1976. Bacterial activity in the hind-gut of pigs. Z. Tierphysiol. Tierernahr. Futtermittelkd. 36:310-324. https://doi.org/10.1111/j.1439-0396.1975.tb01150.x.

Mebus, C. A., E. L. Stair, N. R. Underdahl, and M. J. Twiehaus. 1971. Pathology of neonatal calf diarrhea induced by a reo-like virus. Vet. Pathol. 8:490-505. https://doi.org/10.1177/0300985871008005 -00612 .

Michell, A. R. 1998. Oral rehydration for diarrhoea: Symptomatic treatment or fundamental therapy. J. Comp. Pathol. 118:175-193. https://doi.org/10.1016/s0021-9975(05)80125-2.

Miller, J. K., F. C. Madsen, and E. W. Swanson. 1977. Effects of ingested soil on ration utilization by dairy cows. J. Dairy Sci. 60:618-622. https://doi.org/10.3168/jds.S0022-0302(77)83909-X.

Mir, P. S., J. H. Burton, and J. G. Buchanan-Smith. 1991. Nutritional performance of calves fed milk replacers containing processed soybean products. Can. J. Anim. Sci. 71:97-106. https://doi.org/10 .4141/cjas91-011.

Montagne, L., I. Crévieu-Gabriel, R. Toullec, and J. P. Lallès. 2003. Influence of dietary protein level and source on the course of protein digestion along the small intestine of the veal calf. J. Dairy Sci. 86:934-943. https://doi.org/10.3168/jds.S0022-0302(03)73676 -5 . 
Montagne, L., R. Toullec, M. Formal, and J. P. Lallès. 2000a. Influence of dietary protein level and origin on the flow of mucin along the small intestine of the preruminant calf. J. Dairy Sci. 83:2820-2828. https://doi.org/10.3168/jds.S0022-0302(00)75181-2.

Montagne, L., R. Toullec, and J. P. Lallès. 2000b. Quantitative and qualitative changes in endogenous nitrogen components along the small intestine of the calf. J. Sci. Food Agric. 80:2123-2134. https://doi.org/10.1002/1097-0010(200011)80:14<2123::AIDJSFA761>3.0.CO;2-9.

Montagne, L., R. Toullec, and J. P. Lallès. 2000c. Calf intestinal mucin: Isolation, partial characterization, and measurement in ileal digesta with an enzyme-linked immunosorbent assay. J. Dairy Sci. 83:507-517. https://doi.org/10.3168/jds.S0022-0302(00)74910-1.

Montagne, L., R. Toullec, and J. P. Lallès. 2001. Intestinal digestion of dietary and endogenous proteins along the small intestine of calves fed soybean or potato. J. Anim. Sci. 79:2719-2730. https:// doi.org/10.2527/2001.79102719x.

Montoya, C. A., S. J. Henare, S. M. Rutherfurd, and P. J. Moughan. 2016. Potential misinterpretation of the nutritional value of dietary fiber: Correcting fiber digestibility values for nondietary gut-interfering material. Nutr. Rev. 74:517-533. https://doi.org/ 10.1093/nutrit/nuw014.

Montoya, C. A., S. M. Rutherfurd, and P. J. Moughan. 2015. Nondietary gut materials interfere with the determination of dietary fiber digestibility in growing pigs when using the Prosky method. J. Nutr. 145:1966-1972. https://doi.org/10.3945/jn.115.212639.

Mylrea, P. J. 1966. Digestion of milk in young calves. I. Flow and acidity of the contents of the small intestine. Res. Vet. Sci. 7:333-341. https://doi.org/10.1016/S0034-5288(18)34686-1.

NRC. 2001. Nutrient Requirements of Dairy Cattle. 7th ed. National Academies Press, Washington, DC.

Nyachoti, C. M., C. F. M. de Lange, B. W. McBride, and H. Schulze. 2010. Significance of endogenous gut nitrogen losses in the nutrition of growing pigs: A review. Can. J. Anim. Sci. 77:149-163. https://doi.org/10.4141/a96-044.

Pearson, G. R., D. B. Welchman, and M. Wells. 1987. Mucosal changes associated with abomasal ulceration in veal calves. Vet. Rec. 121:557-559.

Pederson, C. S., and M. N. Albury. 1955. Variation among the heterofermentative lactic acid bacteria. J. Bacteriol. 70:702-708. https:/ /doi.org/10.1128/JB.70.6.702-708.1955.

Petit, H. V., M. Ivan, and G. J. Brisson. 1989. Digestibility measured by fecal and ileal collection in preruminant calves fed a clotting or a nonclotting milk replacer. J. Dairy Sci. 72:123-128. https://doi .org/10.3168/jds.S0022-0302(89)79087-1.

Piel, C., L. Montagne, P. Salgado, and J.-P. Lallès. 2004. Estimation of ileal output of gastro-intestinal glycoprotein in weaned piglets using three different methods. Reprod. Nutr. Dev. 44:419-435. https: //doi.org/10.1051/rnd:2004049.

Plata-Salamán, C. R., and J. M. H. Ffrench-Mullen. 1992. Intracerebroventricular administration of a specific IL-1 receptor antagonist blocks food and water intake suppression induced by interleukin13. Physiol. Behav. 51:1277-1279. https://doi.org/10.1016/0031 -9384(92)90321-r.

Pusztai, A. 1992. Plant Lectins. Cambridge University Press, Cambridge, UK.

Quigley, J. D. III, C. G. Schwab, and W. E. Hylton. 1985. Development of rumen function in calves: Nature of protein reaching the abomasum. J. Dairy Sci. 68:694-702. https://doi.org/10.3168/jds .S0022-0302(85)80875-4.

Raeth, M., H. Chester-Jones, D. Ziegler, B. Ziegler, D. Schimek, D. L. Cook, G. Golombeski, and A. V. Grove. 2016. Pre- and postweaning performance and health of dairy calves fed milk replacers with differing protein sources. Prof. Anim. Sci. 32:833-841. https://doi .org/10.15232/pas.2016-01536.

Rey, M., F. Enjalbert, and V. Monteils. 2012. Establishment of ruminal enzyme activities and fermentation capacity in dairy calves from birth through weaning. J. Dairy Sci. 95:1500-1512. https:// doi.org/10.3168/jds.2011-4902.

Robertson, J. B., and P. J. Van Soest. 1981. The detergent system of analysis and its application to human foods. Pages $123-157$ in The
Analysis of Dietary Fiber in Food. W. P. James and O. Theander, ed. Marcel Dekker, New York, NY.

Rosa, F., S. Busato, F. C. Avaroma, K. Linville, E. Trevisi, J. S. Osorio, and M. Bionaz. 2018. Transcriptional changes detected in fecal RNA of neonatal dairy calves undergoing a mild diarrhea are associated with inflammatory biomarkers. PLoS One 13:e0191599. https://doi.org/10.1371/journal.pone.0191599.

Samloff, I. M. 1971. Pepsinogens, pepsins, and pepsin inhibitors. Gastroenterology 60:586-604. https://doi.org/10.1016/S0016 $-5085(71) 80065-3$.

Sedgman, C. A., J. H. B. Roy, J. Thomas, I. J. F. Stobo, and P. Ganderton. 1985. Digestion, absorption and utilization of single-cell protein by the preruminant calf. Br. J. Nutr. 54:219-244. https:// doi.org/10.1079/bjn19850107.

Senevirathne, N. D., J. L. Anderson, W. R. Gibbons, and J. A. Clapper. 2017. Growth performance of calves fed microbially enhanced soy protein in pelleted starters. J. Dairy Sci. 100:199-212. https:/ /doi.org/10.3168/jds.2016-11221.

Sherrod, P. H. 1991. NLREG: Nonlinear regression analysis program. Accessed Feb. 3, 2020. http://www.nlreg.com/NLREG.pdf.

Siddons, R. C., R. H. Smith, M. J. Henschel, W. B. Hill, and J. W. G. Porter. 1969. Carbohydrate utilization in the pre-ruminant calf. Br. J. Nutr. 23:333-341. https://doi.org/10.1079/bjn19690040.

Smith, R. H. 1963. Small intestine transit time and magnesium absorption in the calf. Nature 198:161-162. https://doi.org/10.1038/ $198161 \mathrm{a} 0$.

Smith, R. H. 1969. Absorption of major minerals in the small and large intestines of the ruminant. Proc. Nutr. Soc. 28:151-160. https://doi.org/10.1079/PNS19690026.

Smith, R. H., and J. W. Sissons. 1975. The effect of different feeds, including those containing soya-bean products, on the passage of digesta from the abomasum of the preruminant calf. Br. J. Nutr. 33:329-349. https://doi.org/10.1079/bjn19750039.

Steele, M. A., G. B. Penner, F. Chaucheyras-Durand, and L. L. Guan. 2016. Development and physiology of the rumen and the lower gut: Targets for improving gut health. J. Dairy Sci. 99:4955-4966. https://doi.org/10.3168/jds.2015-10351.

Stein, H. H., B. Sève, M. F. Fuller, P. J. Moughan, and C. F. M. De Lange. 2007. Invited review: Amino acid bioavailability and digestibility in pig feed ingredients: Terminology and application. J. Anim. Sci. 85:172-180. https://doi.org/10.2527/jas.2005-742.

Steinhoff-Wagner, J., R. Zitnan, U. Schönhusen, H. Pfannkuche, M. Hudakova, C. C. Metges, and H. M. Hammon. 2014. Diet effects on glucose absorption in the small intestine of neonatal calves: Importance of intestinal mucosal growth, lactase activity, and glucose transporters. J. Dairy Sci. 97:6358-6369. https://doi.org/10.3168/ jds.2014-8391.

Sun, P., J. Q. Wang, and H. T. Zhang. 2010. Effects of Bacillus subtilis natto on performance and immune function of preweaning calves. J. Dairy Sci. 93:5851-5855. https://doi.org/10.3168/jds.2010-3263.

Tan, B., Y. Yin, X. Kong, P. Li, X. Li, H. Gao, X. Li, R. Huang, and G. Wu. 2010. L-Arginine stimulates proliferation and prevents endotoxin-induced death of intestinal cells. Amino Acids 38:12271235. https://doi.org/10.1007/s00726-009-0334-8.

Teixeira, A. G. V., F. S. Lima, M. L. S. Bicalho, A. Kussler, S. F. Lima, M. J. Felippe, and R. C. Bicalho. 2014. Effect of an injectable trace mineral supplement containing selenium, copper, zinc, and manganese on immunity, health, and growth of dairy calves. J. Dairy Sci. 97:4216-4226. https://doi.org/10.3168/jds.2013-7625.

Ternouth, J. H., and J. H. B. Roy. 1973. The effect of diet and feeding technique on digestive function in the calf. Annales de Recherches Vétérinaires 4:19-30.

Thaela, M. J., S. G. Pierzynowski, M. S. Jensen, K. Jakobsen, B. R. Weström, and B. W. Karlsson. 1995. The pattern of the circadian rhythm of pancreatic secretion in fed pigs. J. Anim. Sci. 73:34023408. https://doi.org/10.2527/1995.73113402x.

Tukur, H. M., J. P. Lallès, C. Mathis, I. Caugant, and R. Toullec. 1993. Digestion of soybean globulins, glycinin, $\alpha$-conglycinin and $\beta$-conglycinin in the preruminant and the ruminant calf. Can. J. Anim. Sci. 73:891-905. https://doi.org/10.4141/cjas93-091. 
Udén, P., P. E. Colucci, and P. J. Van Soest. 1980. Investigation of chromium, cerium and cobalt as markers in digesta. Rate of passage studies. J. Sci. Food Agric. 31:625-632. https://doi.org/10 .1002 /jsfa.2740310702.

Van Bruchem, J., J. Voight, T. S. C. W. Lammers-Wienhoven, U. Schönhusen, J. J. M. H. Ketelaars, and S. Tamminga. 1997. Secretion and reabsorption of endogenous protein along the small intestine of sheep: Estimates derived from $15 \mathrm{~N}$ dilution of plasma non-protein-N. Br. J. Nutr. 77:273-286. https://doi.org/10.1079/ BJN19970029.

Van Keulen, P., A. C. Welboren, M. A. Khan, F. W. Knol, J. Dijkstra, and S. A. Mccoard. 2017. Brief communication: The effect of arginine supplementation and milk allowance on small intestinal development in pre-weaning calves. Pages $88-90$ in Proc. New Zealand Society of Animal Production, Rotorua, NZ. New Zealand Society of Animal Production, Hamilton, NZ.

van't Klooster, A. T., P. A. M. Rogers, and B. D. E. Gaillard. 1969 Observations on the digestion and absorption of food along the gastro-intestinal tract of fistulated cows. Mededelingen/Landbouwhogeschool Wageningen report no. 69-11. Veenman, Wageningen, the Netherlands.

Wang, J., Q. Diao, Y. Tu, N. Zhang, and X. Xu. 2012. The limiting sequence and proper ratio of lysine, methionine and threonine for calves fed milk replacers containing soy protein. Asian-Australas. J. Anim. Sci. 25:224-233. https://doi.org/10.5713/ajas.2011 11190 .

Williams, V. J., J. H. Roy, and C. M. Gillies. 1976. Milk-substitute diet composition and abomasal secretion in the calf. Br. J. Nutr. 36:317-335. https://doi.org/10.1079/bjn19760090.
Wilms, J., H. Berends, and J. Martín-Tereso. 2019. Hypertonic milk replacers increase gastrointestinal permeability in healthy dairy calves. J. Dairy Sci. 102:1237-1246. https://doi.org/10.3168/jds .2018-15265.

Wise, G. H., and G. W. Anderson. 1939. Factors affecting the passage of liquids into the rumen of the dairy calf. I. Method of administering liquids: Drinking from open pail versus sucking through a rubber nipple. J. Dairy Sci. 22:697-705. https://doi.org/10.3168/ jds.S0022-0302(39)92926-7.

Woyengo, T. A., A. J. Cowieson, O. Adeola, and C. M. Nyachoti. 2009. Ileal digestibility and endogenous flow of minerals and amino acids: Responses to dietary phytic acid in piglets. Br. J. Nutr. 102:428-433. https://doi.org/10.1017/S0007114508184719.

Wu, G., F. W. Bazer, T. A. Davis, S. W. Kim, P. Li, J. Marc Rhoads, M. Carey Satterfield, S. B. Smith, T. E. Spencer, and Y. Yin. 2009. Arginine metabolism and nutrition in growth, health and disease. Amino Acids 37:153-168. https://doi.org/10.1007/s00726 $-008-0210-\mathrm{y}$.

\section{ORCIDS}

I. Ansia (1) https://orcid.org/0000-0002-9114-4178

J. K. Drackley @ https://orcid.org/0000-0002-4560-5594 